\title{
The formation of green rust induced by tropical river biofilm components
}

Running title: Green rust from ferruginous biofilms

5

Frédéric Jorand, Asfaw Zegeye, Jaafar Ghanbaja, Mustapha Abdelmoula

Accepted in Science of the Total Environment

10

IF JCR 2009 (ISI Web) $=2.905$ 


\section{Abstract}

15 In the Sinnamary Estuary (French Guiana), a dense red biofilm grows on flooded surfaces. In order to characterize the iron oxides in this biofilm and to establish the nature of secondary minerals formed after anaerobic incubation, we conducted solid analysis and performed batch incubations. Elemental analysis indicated a major amount of iron as inorganic compartment along with organic matter. Solid analysis

20 showed the presence of two ferric oxides ferrihydrite and lepidocrocite. Bacteria were abundant and represented more than $10^{11}$ cells $\mathrm{g}^{-1}$ of dry weight among which iron reducers were revealed. Optical and electronic microscopy analysis revealed than the bacteria were in close vicinity of the iron oxides. After anaerobic incubations with exogenous electron donors, the biofilm's ferric material was reduced into green rust,

25 a Fe"-Fe"ll layered double hydroxide. This green rust remained stable for several years. From this study and previous reports, we suggest that ferruginous biofilms should be considered as a favorable location for GR biomineralization when redox conditions and electron donors availability are gathered.

30 Keywords: green rust; biofilm; iron oxide; lepidocrocite; ferrihydrite; biomineralization; solid analysis; secondary iron minerals 


\section{INTRODUCTION}

The green rust (GR) compounds are mixed Fe"-Fe"l| layered double hydroxide unstable under oxic conditions, and identified in several sub-oxic environments like corroded surface of Fe-based materials (Refait et al., 2006), hydromorphic soils (Trolard et al., 1997) or ground water (Christiansen et al., 2009). The GR structure is

35 related to that of the mineral fougerite (IMA 2003-057) (Génin et al., 2005; Trolard et al., 2007). The GRs are considered to be key components in biogeochemical cycle of iron (Herbillon, 2006) or in the applied research for polluted soil and water remediation processes due to their high reactivity towards oxidized organic (nitroaromatics, chloride derived, ...) or inorganic compounds $\left(\mathrm{Hg}^{\prime \prime}, \mathrm{Se}^{\mathrm{v}}, \mathrm{Cr}^{\mathrm{v}}, \ldots\right)$

40 (Myneni et al., 1997; Erbs et al., 1999; Loyaux-Lawniczak et al., 2000; Refait et al., 2000; O'Loughlin et al., 2003). However, the mechanisms implied in their formation and whether or not bacteria are a major actor for their precipitation in natural environments, remain under investigation (Zegeye et al., 2005 ; Zegeye et al., 2007a ; Ahmed et al., 2010 ; Salas et al., 2010 ; Zegeye et al., 2010).

The dissimilatory iron-reducing bacteria (DIRB) are well recognized to be involved in the formation of secondary iron-II minerals. By coupling the reduction of Fe"II to the oxidation of hydrogen or organic matter they gain energy for growth and the resulting $\mathrm{Fe}^{\prime \prime}$ mainly precipitates in several mineral phases such as magnetite $\left(\mathrm{Fe}_{3} \mathrm{O}_{4}\right)$, siderite $\left(\mathrm{FeCO}_{3}\right)$, chukanovite $\left(\mathrm{Fe}_{2} \mathrm{OH}_{2}\left(\mathrm{CO}_{3}\right)\right)$, vivianite $\left(\mathrm{Fe}_{3}\left(\mathrm{PO}_{4}\right)_{2} \cdot 8 \mathrm{H}_{2} \mathrm{O}\right)$, the hydroxycarbonate green rust $1\left(\mathrm{Fe}_{4}{ }_{4} \mathrm{Fe}_{2}{ }_{2}(\mathrm{OH})_{12} \mathrm{CO}_{3} \cdot 3 \mathrm{H}_{2} \mathrm{O}\right)$ and the hydroxysulfate green rust $2\left(\mathrm{Fe}_{4}{ }_{4} \mathrm{Fe}{ }_{2}(\mathrm{OH})_{12} \mathrm{SO}_{4} \cdot \sim 8 \mathrm{H}_{2} \mathrm{O}\right)$ (Lovley et al., 1987; Jorand et al., 2001; Glasauer et al., 2002; Ona-Nguema et al., 2002; Kukkadapu et al., 2005; Zegeye et al., 2005). The nature of the secondary iron mineral is partly controlled by the 
presence of its chemical constituents. For instance, phosphate or sulfate are needed to form vivianite or $\mathrm{GR} 2\left(\mathrm{SO}_{4}{ }^{2-}\right)$, respectively. But lower phosphate, concentration (i.e. undersaturated for vivianite precipitation) plays additional role, as organic polymers, bacterial cells or silicate, which is to promote the formation of GR over the magnetite without being constituent of this mineral. Thus, the supplementation of the incubation medium by microbial or synthetic polymers (polyacrylate) or autoclaved cells (Zegeye et al., 2007a; Jorand et al., 2008; O’Loughlin et al., 2010; Zegeye et al., 2010), phosphate (Kukkadapu et al., 2004), quartz particles $\left(\mathrm{SiO}_{2}\right)$, silicic acid $\left(\mathrm{H}_{4} \mathrm{SiO}_{4}\right)$ or a panel of oxyanions (O'Loughlin et al., 2010; Sergent et al., 2010) significantly promote the formation of GR1 over magnetite from lepidocrocite or ferrihydrite bioreduction.

The mechanisms involved in such secondary iron biomineralization remains under investigation. Recently, the organization of mixed aggregates constituted by iron oxide and bacterial cells was proposed to influence the GR vs magnetite mineralization routes (Zegeye et al., 2010). It was suspected that an aggregate constituted by densely packed particles promotes areas at a micro-scale level. These 70 micro-area would exhibit high concentrations of both bicarbonate and Fe", resulted from the bacterial metabolism, which would explain the formation of GR. Competitive binding site of oxyanions and $\mathrm{Fe}^{\mathrm{II}}$ onto ferric oxide surface was also suggested as a factor controlling the nature of the bioreduction product (O'Loughlin et al., 2010) as well as the iron reduction rate (Ona-Nguema et al., 2003). In addition, since the 75 carbonated GR1 is relatively unstable as regards to magnetite (Tronc et al., 1992), it has been suggested that the components cited above (phosphate, polymers or silicate), could also promote the formation of GR by playing a protective role on the 
GR crystals. The sorption of anionic components onto the crystals, especially on the lateral faces, would impair their dissolution and thus their subsequent transformation

80 into magnetite (Benali et al., 2001; Bocher et al., 2004; Sergent et al., 2010). In natural environments, bacteria are usually present in association with complex organic matter, heterogenous and diverse minerals and inorganic particles. For instance, biofilms, which are a widespread form of life for bacteria, are mainly constituted by an arrangement of bacteria embedded in exo-cellular polymeric substances (EPS) (De Beer and Stoodley, 2006). Thus, since the presence of EPS and large cell densities were identified to be favorable factors for the (bio)mineralization of GR, as afore mentioned, one could expect that biofilms, especially those rich in iron, display a suitable environment for the GR's formation. However, to our knowledge, the formation of GR in a more complex environmental media or from a biofilm material remains poorly studied. Recently, one study has reported the formation of a GR1 by anaerobic incubation of a ferric material collected from a groundwater seep (Blöthe and Roden, 2009).

The purpose of this study was therefore to evaluate the potentiality of a biofilm material to promote the formation of GR and other Fe" phases. To that end, we used ferruginous biofilms present in the Sinnamary Estuary (Atlantic Ocean, French Guiana), a well-described mercury contaminated area, due to past and present anthropic activity (Dominique et al., 2007; Muresan et al., 2008). We evaluated the capability of the biofilm components to display an iron reducing activity and to promote the formation of GR especially because of its high reactivity towards pollutants such as cationic mercury. 


\section{MATERIALS AND METHODS}

\subsection{Sites and biofilm sampling}

The biofilm samples were collected in the Sinnamary Estuary in French Guiana (Figure 1) where a hydroelectric dam was built in 1994. The resulting reservoir has flooded more than $350 \mathrm{~km}^{2}$ of tropical rainforest inducing a major disturbances of

110 biogeochemical cycles in both the reservoir and the Sinnamary Estuary downstream the dam (Richard et al., 1997; De Mérona et al., 2005). For example the biodegradation of the huge immersed biomass has led to a significant decrease of the $E_{\mathrm{h}}$ in the water column, decreasing the $\mathrm{O}_{2}$ level from $7.2 \mathrm{mg} \mathrm{l}^{-1}$ in 1992 to $0.4 \mathrm{mg} \mathrm{l}^{-}$ ${ }^{1}$ just after the dam from 1995 to present (Richard et al., 1997; Dominique, 2006). As

115 a result, the dam effluent water is significantly concentrated in reduced species such as soluble $\mathrm{Fe}^{\text {"I }}$ species (up to $15-20 \mu \mathrm{mol} \mathrm{I}^{-1}$ ) (Muresan et al., 2008) and increased by a factor 10 (from $2 \mu \mathrm{mol} \mathrm{I}^{-1}$ to $23 \mu \mathrm{mol} \mathrm{I}^{-1}$ ) after the dam construction (Dominique, 2006). These Fe" species are probably the precursor of the red flocs transported by the estuary river and of the thick red-brown slimes recovering any surface in contact

120 with the water up to $\sim 30 \mathrm{~km}$ after the dam (Figure 2a, b). In addition, the anaerobic conditions occurring in the reservoir contribute to the formation of the methyl mercury in the Sinnamary Estuary (Dominique et al., 2007; Muresan et al., 2008). The samples were collected between March 2005 and March 2008 at three sampling stations: i) the Passerelle station (N503'54", W5303’08”); ii) the Vénus station

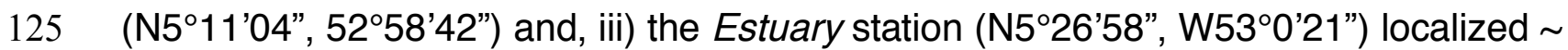
$0.8 \mathrm{~km}, \sim 20 \mathrm{~km}$ and $\sim 65 \mathrm{~km}$ after the Petit-Saut dam respectively (Figure 1). 
The biofilms were collected at the Passerelle and Vénus stations and the surface sediments at the Estuary station. They were collected by scrapping the surfaces (immersed rope, branches, rock) with a sterile spoon and poured into sterile boxes in polypropylene filled with the river water. At the Estuary, the surface sediments were mainly sand-like deposit ( $50 \mathrm{~cm}$ depth) in the hollow of a rock. The samples were transported to the laboratory station in an isotherm container (Chest 36QT, Coleman $^{\circledast}$, Wichita, KS) under one to five hours. Aliquot of these samples were stored in refrigerated conditions (isotherm container with ice-pack, around $4^{\circ} \mathrm{C}$ )

135 during aircraft transportation to the metropolitan laboratory two weeks after the sampling, or were used on site immediately ("freshly used"). When the samples served both as Fe"ll source and inocula they were used directly after their collection; when they served as $\mathrm{Fe}^{\mathrm{III}}$ source only, they were lyophilized after transportation.

\subsection{Biomineralization assays}

The biomineralization assays were conducted in three ways (Table 1):

- Biofilms as Fe"ll source: consisted of anaerobic incubations of lyophilized biofilms supplemented with an electron donor and a cell suspension of an iron reducing

145 bacteria.

- Biofilms (or surface sediments) as inocula : consisted of incubations of synthetic lepidocrocite $\left(\gamma-\mathrm{FeOOH}\right.$, as $\mathrm{Fe}^{\text {III }}$ source) with autochtonous bacteria as inoculum and supplemented with an electron donor.

- Biofilms as inocula and Fe"II source : consisted of incubations of the fresh biofilm components just supplemented with electron donors. 


\subsection{Biofilms as Fe $e^{\prime \prime \prime}$ source}

Dense resting cell suspensions of Shewanella putrefaciens CIP80.40 (Collection of

155 Institut Pasteur, Paris, France) were obtained after a $24 \mathrm{~h}$ aerobic culture in tryptcase soy broth (30 $\mathrm{g} \mathrm{l}^{-1}, 51019$, BioMérieux, Marcy l'Étoile, France) and washed twice (centrifugation $10,000 \times g ; 10 \mathrm{~min} ; 20^{\circ} \mathrm{C}$ ) with $0.7 \% \mathrm{NaCl}$ solution. A series of duplicates of $100 \mathrm{ml}$ serum bottles (sealed with thick butyl rubber stoppers, Bellco Glass Inc., Vineland, NJ) were prepared and contained $8.410^{8}$ and $3.210^{9}{\text { cells } \mathrm{ml}^{-1}}^{-1}$

160 (final concentration) with sodium-formate (NaHCOO) $70 \mathrm{mmol} \mathrm{I}^{-1}$ as the sole electron donor in a sterile mineral medium in pure water (MilliRO/MilliQ+, Millipore, Billerica) as previously described (Zegeye et al., 2007a): $22 \mathrm{mmol}^{-1} \mathrm{NH}_{4} \mathrm{Cl}, 1.5 \mathrm{mmol} \mathrm{l}^{-1} \mathrm{NaCl}$, $1.2 \mathrm{mmol} \mathrm{I}^{-1} \mathrm{KCl}, 1.1 \mathrm{mmol} \mathrm{I}^{-1} \mathrm{MgSO}_{4} \cdot 7 \mathrm{H}_{2} \mathrm{O}, 0.71 \mathrm{mmol} \mathrm{I}^{-1}$ nitrilotriacetic acid, 0.67 $\mathrm{mmol} \mathrm{I}^{-1} \mathrm{CaCl}_{2}, 0.27 \mathrm{mmol} \mathrm{I}^{-1} \mathrm{MnSO}_{4} \cdot \mathrm{H}_{2} \mathrm{O}, 133 \mu \mathrm{mol} \mathrm{l}^{-1}$ anthraquinone disulfonate

165 (ADQS), $86 \mu \mathrm{moll}^{-1} \mathrm{ZnCl}_{2}, 38 \mu \mathrm{moll}^{-1} \mathrm{CoSO}_{4} \cdot 7 \mathrm{H}_{2} \mathrm{O}, 32 \mu \mathrm{mol} \mathrm{I}^{-1} \mathrm{FeSO}_{4} \cdot 7 \mathrm{H}_{2} \mathrm{O}, 9.3$ $\mu \mathrm{mol} \mathrm{I}{ }^{-1} \mathrm{Na}_{2} \mathrm{MoO}_{4} \cdot 2 \mathrm{H}_{2} \mathrm{O}, 9.1 \mu \mathrm{mol} l^{-1} \mathrm{NiCl}_{2} \cdot 6 \mathrm{H}_{2} \mathrm{O}, 6.8 \mu \mathrm{mol} l^{-1} \mathrm{Na}_{2} \mathrm{WO}_{4} \cdot 2 \mathrm{H}_{2} \mathrm{O}, 3.6 \mu \mathrm{mol}$ $\mathrm{I}^{-1} \mathrm{CuSO}_{4} \cdot 5 \mathrm{H}_{2} \mathrm{O}, 1.9 \mu \mathrm{mol} \mathrm{I}{ }^{-1} \mathrm{AlK}\left(\mathrm{SO}_{4}\right)_{2} \cdot 12 \mathrm{H}_{2} \mathrm{O}, 1.5 \mu \mathrm{mol} \mathrm{I}^{-1} \mathrm{H}_{3} \mathrm{BO}_{3}$. Finally, $25 \mathrm{~g} \mathrm{l}^{-1}$ of the lyophilized biofilm were added. The Fe $\mathrm{e}^{\text {III }}$ present in this biofilm (170 $\mathrm{mmol}^{-1} \mathrm{Fe}^{\text {III }}$ equivalent) was assumed to be the sole electron acceptor. This lyophilized biofilm extract was not heat sterilized in order to avoid any modifications of the iron oxide minerals. All other constituents than lyophilized biofilm and Shewanella cells have been heat sterilized, except formate and AQDS which were sterilized by filtration. A control was done in the same conditions except that no resting cells of $S$. putrefaciens was added. 


\subsection{Biofilms as inocula}

One $\mathrm{ml}$ of a biofilm suspension collected at Passerelle and Vénus stations, or from surface sediment (Estuary station), served as inoculum for $9 \mathrm{ml}$ of the following anaerobic culture medium (final concentration in purified water): suspension of $5.3 \mathrm{~g} \mathrm{l}^{-}$ ${ }^{1} \mathrm{y}$-FeOOH (i.e. : $60 \mathrm{mmol} \mathrm{I}^{-1}$ equiv. $\mathrm{Fe}^{\mathrm{III}}$ ) as electron acceptor; $5 \mathrm{mmol} \mathrm{I}^{-1}$ sodium formate, $5 \mathrm{mmol} \mathrm{I}^{-1}$ sodium acetate, $2.5 \mathrm{mmol} \mathrm{I}^{-1}$ sodium lactate as electron donor mix. The basal and mineral medium contained (final concentration in pure water): 30 $\mathrm{mmol} \mathrm{I}^{-1} \mathrm{NaHCO}_{3}, 4.5 \mathrm{mmol} \mathrm{l}^{-1} \mathrm{NH}_{4} \mathrm{Cl}, 4 \mathrm{mmol} \mathrm{I}^{-1} \mathrm{NaH}_{2} \mathrm{PO}_{4} \mathrm{H}_{2} \mathrm{O}, 1.3 \mathrm{mmol} \mathrm{I}^{-1} \mathrm{KCl}, 0.1$

$185 \mathrm{mmol} \mathrm{I}^{-1} \mathrm{MgSO}_{4}, 30 \mu \mathrm{mol} \mathrm{I}^{-1} \mathrm{MnSO}_{4}, 8 \mu \mathrm{mol} \mathrm{I}^{-1} \mathrm{CoSO}_{4}, 7 \mu \mathrm{mol} \mathrm{I}^{-1} \mathrm{CaCl}_{2}, 7 \mu \mathrm{mol} \mathrm{l}^{-1}$ $\mathrm{ZnSO}_{4}, 1.5 \mu \mathrm{mol} \mathrm{I}^{-1} \mathrm{H}_{3} \mathrm{BO}_{3}, 1 \mu \mathrm{mol} \mathrm{I}^{-1} \mathrm{Na}_{2} \mathrm{SeO}_{4}, 1 \mu \mathrm{mol} \mathrm{I}^{-1} \mathrm{NiCl}_{2} \cdot 6 \mathrm{H}_{2} \mathrm{O}, 0.7 \mu \mathrm{mol} \mathrm{l}^{-1}$ $\mathrm{Na}_{2} \mathrm{WO}_{4} \cdot 2 \mathrm{H}_{2} \mathrm{O}, 0.5 \mu \mathrm{mol} \mathrm{I}^{-1} \mathrm{Na}_{2} \mathrm{MoO}_{4} \cdot 2 \mathrm{H}_{2} \mathrm{O}, 0.4 \mu \mathrm{mol} \mathrm{I}^{-1} \mathrm{CuSO}_{4}, 0.3 \mu \mathrm{mol} \mathrm{I}^{-1}$ $\operatorname{AlK}\left(\mathrm{SO}_{4}\right)_{2} \cdot 12 \mathrm{H}_{2} \mathrm{O}$. AQDS $\left(100 \mu \mathrm{mol} \mathrm{I}^{-1}\right)$ were added with the mix of electron donors, previously sterilized by filtration into the autoclaved medium. Vitamins were added

190 from filtered sterilized stock solutions containing (in final concentration) $20 \mu \mathrm{g} \mathrm{l}^{-1}$ biotin, $20 \mu \mathrm{g} \mathrm{l}^{-1}$ folic acid, $100 \mu \mathrm{g} \mathrm{l}^{-1}$ pyridoxine $\mathrm{HCl}, 50 \mu \mathrm{g} \mathrm{I}^{-1}$ riboflavin, $50 \mu \mathrm{g} \mathrm{l}^{-1}$ thiamine, $50 \mu \mathrm{g} \mathrm{I}^{-1}$ nicotinic acid, $50 \mu \mathrm{g} \mathrm{l}^{-1}$ pantothenic acid, $1 \mu \mathrm{g} \mathrm{I}^{-1} \mathrm{~B}-12,50 \mu \mathrm{g} \mathrm{l}^{-1}$ para-aminobenzoic acid, and $50 \mu \mathrm{g} \mathrm{I}^{-1}$ thiotic acid. The lepidocrocite was chemically synthesized according to the method described by Zegeye et al. (2007a).

195 Lepidocrocite wad preferentially chosen due to its stability during the heat sterilization of the medium but also because this mineral was suitable for GR biomineralization (Ona-Nguema et al., 2002) and finally because it was identified, as it will be indicated below in the manuscript, to be the main mineral constituting the present ferruginous biofilm. 


\subsection{Biofilms as inocula and Fe $e^{\prime \prime \prime}$ source}

Freshly harvested biofilms from Passerelle station were poured into $100 \mathrm{ml}$ serum bottles filled with the Sinnamary Estuary water (composition described in Table 2).

205 The suspension obtained was supplemented with $10-30 \mathrm{ml}$ of a mix of electron donors in different proportions (Table 1). It was assumed that the biofilm components provided the Fe $\mathrm{F}^{\mathrm{II}}$ as the main electron acceptor. At the start of the experiments, the Fe $e^{\text {III }}$ amount in the biofilm was not measured yet, therefore three ratio of electron donor mix / biofilm suspension were tested. The determination of Fe later on

210 indicated that on the one hand two assays contained 22 and $31 \mathrm{mmol} \mathrm{I}^{-1}$ of Fe $\mathrm{Fe}^{\mathrm{III}}$ with an electron donor concentration of 4,4 , and $2 \mathrm{mmol} \mathrm{I}^{-1}$ for acetate, formate and lactate respectively; and on the other hand the third assay contained $57 \mathrm{mmol}^{-1}$ of Fe $\mathrm{e}^{\mathrm{III}}$ with an electron donor concentration of 15,15 , and $7.5 \mathrm{mmol} \mathrm{I}^{-1}$ for acetate, formate and lactate respectively (Table 1).

All incubation media were purged with $\mathrm{O}_{2}$-free $\mathrm{N}_{2}(99.99 \%)$ gas for 30 min in aseptic condition. All the assays displayed a $\mathrm{pH}$ of $6.5 \pm 0.2$ and were incubated at $30^{\circ} \mathrm{C}$ in the dark.

\subsection{Analytical techniques}

The dry weight (DW) of the biofilm samples were measured in the Hydreco Laboratory facilities (Kourou, French Guyana) few hours after sampling. The weight of a desiccated pellets was measured from a $10 \mathrm{ml}$ biofilm suspension centrifuged for

$2255 \mathrm{~min}$ at $10,000 \times g$ and dried at $105^{\circ} \mathrm{C}$ over night. The ash content was measured 
after $3 \mathrm{~h}$ of calcination $\left(550^{\circ} \mathrm{C}\right)$ and the ash free dry weight was then calculated by difference. The total iron content ( $\left.\mathrm{mg} \mathrm{g}^{-1} \mathrm{DW}\right)$ has been performed by ICP-AES after acidic digestion in $\mathrm{HCl} 6 \mathrm{~N}$.

The Fe ${ }^{\text {III }}$ reduction was monitored by measuring the Fe" accumulation over time. The amount of total Fe" (i.e. in the solid and soluble phases) extracted by $\mathrm{HCl} 5 \mathrm{~mol} \mathrm{I}^{-1}$ was determined with ortho-phenanthroline (Fadrus and Maly, 1975). The soluble Fe" was assessed after filtration through $0.2 \mu \mathrm{m}$ membrane filter (Millex-GP SLGP, Millipore, Billerica, MA) in an anaerobic chamber $\left(\mathrm{N}_{2} / \mathrm{H}_{2}, 97 / 3\right.$, Coy Laboratory Product Inc., Grass Lake, MI, USA).

235 The cell numbers were determined by the epifluorescence microscopy technique using the SYBR green I fluorochrome as a dye (InVitrogen) on the biofilm suspension, previously dispersed by ultrasonic bath treatment (15 min, $120 \mathrm{~W}, \mathrm{RK} 31$, 35KHz, Sonoclean, Paris, France).

\subsection{Solid analysis}

Surface elemental composition of the lyophilized biofilm has been determined by Xray photoelectron spectroscopy (XPS). XPS spectra were recorded using a KRATOS Axis Ultra spectrometer instrument with a monochromatic Al K $\alpha$ Xray (hv = 1486.6

$245 \mathrm{eV}$ ) with the same procedure and apparatus than Zegeye et al. (2007b).

The solids were also characterized by X-ray diffraction (XRD), transmission electron microscopy (TEM), scanning electron microscopy (SEM), Raman spectroscopy (RS), and Mössbauer spectroscopy (MS). The XRD data were collected with a D8 Bruker diffractometer, equipped with a scintillator detector. The X-ray source was a Co 
250 anode $(\lambda=0.17902 \mathrm{~nm})$. The diffractograms were recorded in the $3-64^{\circ} 2 \theta$ range, with a $0.035^{\circ}$ step size and a collecting time of 3 seconds per point.

The suspension was filtered under $\mathrm{N}_{2}$ atmosphere, mixed with glycerol to avoid oxidation and placed on a sample carrier to be analyzed by XRD.

For TEM observation, one drop of the suspension was laid on an amorphous carbon-

255 coated grid and the sample was loaded into the microscope (Philips CM20/STEM).

The relative element composition of the analyzed solids was obtained by energy dispersive X-ray analysis (EDX). For the scanning electronic microscopy (SEM) examination, one drop of the sample was sprinkled onto $2 \mathrm{~cm}^{2}$ plates and examined under vacuum (Hitachi 54800 Scanning Electron Microscopy).

260 A Raman characterization was performed with a special cell used for Raman experiments. The sample was set under an $\mathrm{N}_{2}-\mathrm{O}_{2}$ free atmosphere in an anaerobic chamber and the cell was tightly closed by a glass window through which a laser beam was focused and the Raman backscattering collected. The cell is mounted in the focal plane of an Olympus B.H. microscope in a Jobin-Yvon/Instrument S.A. T

26564000 Raman microprobe equipped with charged coupled device detector and a motorized $X-Y$ stage. A large working distance objective length of $50 \mathrm{x}$ magnification was used. A $514.53 \mathrm{~nm}$ exciting radiation was used with a power $\sim 0.2 \mathrm{~mW}$ to prevent sample degradation. The spectra resolution was about of $6 \mathrm{~cm}^{-1}$ and the precision on the wavenumber was $1 \mathrm{~cm}^{-1}$. Two successive scan of $90 \mathrm{~s}$ were performed.

270 The Mössbauer spectroscopy (MS) was performed from 12 to $295 \mathrm{~K}$ with a closed helium cycle variable temperature Mössbauer cryostat equipped with vibration isolation stand manufactured by Advanced Research Systems (ARS), utilizing a constant acceleration Mössbauer spectrometer with a $50 \mathrm{mCi}$ source of ${ }^{57} \mathrm{Co}$ in $\mathrm{Rh}$ 
and calibrated with a $25 \mu \mathrm{m}$ thick a-Fe foil at ambient temperature. Spectra were

275 fitted using Lorentzian-shape lines and parameters were mathematically (minimization of $\chi^{2}$ ) and physically significant.

\subsection{Microscopy for cells and biofilm matrix observations}

280 The embedding technique previously described by Droppo et al. (1996) has been modified and adapted to the ferruginous biofilms. Briefly, freshly handled fragments of biofilms with their substrata (nylon rope) were poured into $10 \mathrm{ml}$ of estuarine water containing $4 \%$ of glutaraldehyde. After the settlement of the fragments $(\sim 2 \mathrm{~h})$, the supernatant was gently removed and replaced by a solution of low-melting-point

285 electrophoresis grade and sterile agarose (0.75\%). After solidification (and transportation until the metropolitan laboratory in isotherm boxes) the samples were dewatered in ethanol and in propylene oxide, and embedded in epoxy resin. Finally, thin and ultra-thin sections were stained with Azur blue II or lead nitrate respectively prior to examination with the optical microscopy or TEM respectively.

\section{Results}

\subsection{Characterization of the ferruginous biofilms}

The biofilm recovering all surfaces in contact with the water of the Sinnamary Estuary appeared as a brown-orange color gluying slime (Figure 2a, b) being in some areas up to $\sim 1 \mathrm{~cm}$ thick. As expected, iron was the major inorganic part of the biofilms from Passerelle and Vénus stations and accounted for 0.37 and $0.20 \mathrm{~g} \mathrm{~g}^{-1}$ of the dry 
weight according to ICP-AES analysis, respectively (Table 2). The XPS analysis confirmed the presence of an important amount of iron into the biofilm. The oxide component located at $530.9 \mathrm{eV}$ in the $\mathrm{O}_{1} \mathrm{~s}$ spectrum (Table SI-1) indicated that the iron was involved in a ferric oxide phase. The organic matter represented approx. 35 $\%$ of the DW part of the ash free dry weight measure (Table 2). In addition to oxygen,

305 the significant amount of N, C and S was in agreement with the presence of organic matter. Optical microscopic observation indicated the presence of copious amount of various microorganisms like diatoms (not shown) and bacterial colonies embedded in an organic or Fe-bearing gel like matrix (Figure 2c). Iron oxides were present in close vicinity to bacterial cells (Figure $2 \mathrm{~d}$ ).

310 The Table 2 indicates that microbial cells accounted for a significant part of the biofilm constituents with $1.3-6 \times 10^{11}$ cells $\mathrm{g}^{-1} \mathrm{DW}$. According to their composition these biofilms can be well qualified as a ferruginous one.

TEM and XRD analyses of the inorganic phases indicated amorphous or slightly diffracting materials. Two Fe-phases were discerned. The first one showed a

315 "crumpled paper" like structure, and gave an electron diffraction pattern consistent with the lepidocrocite $(\gamma-\mathrm{FeOOH})$ (Fig. $2 \mathrm{e}$ and Table SI-2). The X-ray diffraction pattern exhibited the major band specific to $\mathrm{SiO}_{2}$ but also very broad bands localized in the same area of those of lepidocrocite and in a lower trend of ferrihydrite (Fig. 3a). The second Fe-phase did not display a diffraction spectrum with the electron beam 320 and exhibited a granular trend (Fig. 2f). Fe and $\mathrm{O}$ were the major elements of those two phases, along with $\mathrm{Si}, \mathrm{Al}, \mathrm{Na}$, and $\mathrm{Cl}$ in a lower amount according to $\mathrm{EDX}$ analysis (not shown). The presence of both $\gamma-\mathrm{FeOOH}$ and ferrihydrite was in agreement with Raman spectroscopy analyses. The spectrum of the lyophilized 
biofilm (spectra $a$ in Fig. 3b) shows band at $250 \mathrm{~cm}^{-1}$, a broad band in the area of 375 $\mathrm{cm}^{-1}$ and a very broad band in the area of $700 \mathrm{~cm}^{-1}$ matching well with the spectra of synthetic lepidocrocite and ferrihydrite (spectra $c$ and $b$, respectively) (Fig. 3b). The room temperature Mössbauer spectrum of the ferruginous biofilms exhibited a broadened doublet, which can be fitted reasonably with two paramagnetic quadrupole components $D_{L}$ and $D_{F}$ (Fig. Sl-3). The two doublets were distinct in their quadrupole splittings (0.55 and 0.91$)$ whereas their isomer shifts were identical. According to the literature, the component $\mathrm{D}_{\mathrm{L}}$ (Table SI-3) characterized by the isomer shift of 0.33 and the quadrupole splitting of $0.55 \mathrm{~mm} / \mathrm{s}$ corresponds to lepidocrocite (Murad and Schwertmann, 1984). The other component $D_{F}$, with the same isomer shift $(0.35 \mathrm{~mm} / \mathrm{s})$, and a larger quadrupole splitting of $0.91 \mathrm{~mm} / \mathrm{s}$

335 characterizes ferryhydrite. The Mössbauer spectroscopy confirmed therefore that lepidocrocite and ferrihydrite were the main Fe"ll oxides of the biofilm. In addition, it enlighten that lepidocrocite and ferrihydrite contributed to $3 / 4$ (74\%) and 1/4 (26\%) of the whole solid Fe phase, respectively (Table SI-3).

\section{$340 \quad$ 3.2. Bioreduction of Fe ${ }^{\prime \prime \prime}$ material}

Up to $63 \%$ of the lyophilized ferruginous biofilm's Fe ${ }^{\text {III }}$ were reduced by $S$. putrefaciens after 70 days of incubation (Table 1 and Fig. 4). After 800 days, the amount of $\mathrm{Fe}^{\|}$formed did not change indicating that the equilibrium in term of Fe"

345 level was attained after 70 days. A slight $\mathrm{Fe}^{\text {III }}$ reduction was noted in the control (without Shewanella cells) (Fig. 4) probably due to a residual activity of iron reducing bacteria in the lyophilized sample. This was supported by the growth of some colonies in anaerobic as well as in aerobic incubation on solid medium (TS agar) (not 
shown). Thus, it indicates that at least $2 / 3$ of the total Fe was available for

350 bioreduction. In addition, no significant difference, in terms of iron reduction extent and initial iron reduction rate $\left(16 \pm 4 \mathrm{mmol} \mathrm{I}^{-1}\right.$ day $^{-1}$, from data of Fig. 4 fitted as a first order kinetic) was clearly evidenced between the assays containing $8.4 \times 10^{8}$ cells ml${ }^{-1}$ (named LC for "low" cell density) and those with $3.2 \times 10^{9}$ cells $\mathrm{ml}^{-1}$ (named HC for "high" cell density) (Fig. 4).

355 The "aqueous Fe" $(<0.2 \mu \mathrm{m})$ was very low in all samples $\left(<20 \mu \mathrm{mol} \mathrm{I}^{-1}\right)$ (at 70 days) clearly indicating that Fe" was mainly under a solid state.

\subsection{Ability of autochtonous cells to reduce iron oxide}

360 After six months of incubation time, up to $39 \%$ of $\gamma$-FeOOH were reduced by the biofilm (Passerelle and Vénus) and the surface sediment (Estuary) aliquots indicating the presence of iron reducing bacteria in those samples (Table 1). The anaerobic incubation of the freshly sampled biofilm supplemented with electron donor mix (that is to say the fresh biofilm served both as iron oxide and iron reducing bacteria sources), revealed the reduction of $59 \pm 6 \%$ of the ferric oxides after 180 days (Table 1). An increase of nearly two units of $\mathrm{pH}$ was noted (6.5 to 8.5, Table 1$)$ as it is usually observed during the Fe"I reduction in weakly buffered medium (Ona-Nguema et al., 2002; Zegeye et al., 2007a).

Therefore, the biofilms and surface sediment samples exhibited an efficient iron

370 reducing activity to reduce up to $2 / 3$ of the endogenous $\mathrm{Fe}^{\text {III }}$ or exogenic iron oxide (synthetic lepidocrocite). 


\subsection{Characterization of the secondary iron minerals}

375 The analysis by XRD and TEM of the solid phase clearly indicated the presence of GR1 in both the incubation assays when the biofilm served as Fe"l' source (lyophilized biofilm inoculated with S. putrefaciens) and as inocula (synthetic lepidocrocite inoculated with $10 \% \mathrm{v} / \mathrm{v}$ fresh sample extract) (Table 1). In the first case the GR1 was identified by XRD, TEM and MS after 70 and 800 days

380 of incubation as the major solid Fe phase for the two cell concentrations tested. XRD displayed no other characteristic and significant peaks, except a weak one for magnetite, than those of the GR1 after 70 days (Fig. 5) indicating that the GR1 was the major ferrous crystalline phase. However, in the LC (low cell density) assays, the GR1 signal intensity appeared lower suggesting a poor crystallinity of the solids in

385 those samples. After 800 days of incubation, the GR1 still remained the major crystalline phase (at a level discernable by XRD) despite of a stronger signal intensities for the magnetite and the apparition of a calcium magnesium iron carbonate. In the control, no significant peak was detected (Fig. 5). The TEM examination showed crystals with a rounded shape (Fig. 6a), and by SEM they

390 looked-like amorphized GR platelet (Fig. 6b). Those crystals exhibited a diffraction pattern characteristic of the GR1 (Fig. 6a and Table SI-4). The Mössbauer spectrum at room temperature (Fig. SI-3) displayed a mixture of a component (four doublets in the center of the spectrum) in a paramagnetic state and at higher energy, two sextets $\mathrm{S}_{1}$ and $\mathrm{S}_{2}$ in magnetically ordered states. Theses sextets were attributed respectively

395 to iron in tetrahedral $\left(\mathrm{Fe}^{3+}\right)$ and octahedral $\left(\mathrm{Fe}^{2.5+}\right)$ sites in the magnetite crystal. The intensity ratio between $S_{1}$ and $S_{2}$ of about 2 concurred likely with a stoichiometric magnetite. The four doublets obtained in the center of the spectrum correspond to 
two $\mathrm{Fe}^{2+}$ doublets (large values of quadrupole splitting and isomer shift) and to two $\mathrm{Fe}^{3+}$ doublets (small value of quadrupole splitting an isomer shift). The hyperfine

400 parameters (Table SI-5) confirmed the presence of the GR in this sample (Refait et al., 2006), thus supporting the diffraction results (XRD and TEM). The Mössbauer spectroscopy confirmed also the presence of another Fe" bearing mineral (probably the calcium magnesium iron carbonate) and indicated a remaining of Fe $\mathrm{F}^{\text {III }}$ source. The three phases, GR, magnetite and calcium magnesium iron carbonate counted for $60 \%, 20 \%$ and $13 \%$ of the total iron respectively. The fourth phase, the residual lepidocrocite, accounted for 7\% (Table SI-5).

In the second case (assays with biofilms as inocula for synthetic lepidocrocite reduction), some GR crystals were observed by optical microscopy or by TEM examination (Fig. 6c\&d) and XRD analysis confirms the presence of GR phase with

410 vivianite $\left(\mathrm{Fe}_{3}\left(\mathrm{PO}_{4}\right)_{2} \cdot 8 \mathrm{H}_{2} \mathrm{O}\right)(\mathrm{Fig}$. Sl-4) due likely to the presence of phosphate in the culture medium.

The observation by optical microscopy of the solids from the incubation with biofilm serving both as electron acceptor and inoculum, showed several green rust-like colored particles (Fig. 6f). In order to discriminate those particles with cell-bearing

415 chlrorophyll, the suspension was examined under UV light. Some green particles were red fluorescent corresponding to photosynthetic cells, but other green particles were non-fluorescent under UV light excluding the fact that they correspond to cellcontaining chlorophyll. Particles exhibiting the same size $(\sim 1 \mu \mathrm{m})$ were observed under TEM. They gave an electronic diffraction pattern corresponding to an

420 hexagonal symmetry (Fig. 6e) and the other 1.6 time higher than the $d_{\text {hkl }}\{101\}$ exhibiting (0.441 $\mathrm{nm}$ against 0.272$)$. TEM-EDX indicated that these particles were 
constituted by $34 \pm 2 \%$ and $66 \pm 2 \%$ of Fe and $\mathrm{O}$, respectively. However, the other solid analysis methods, like XRD, Raman spectroscopy or MS, did not provide any exploitable results due probably to the low amount of samples in the assays.

\section{Discussion}

\subsection{Ferric iron oxides and bacteria in the biofilm}

430 A growing body of literature indicates that biofilm materials, cell surface appendages or exo-polymeric substances contribute significantly to the secondary iron biomineralization (Ferris et al., 1986; Brown et al., 1994; Brown et al., 1998; Salas et al., 2010). The most accepted mechanism is that cell surface could play the role of nucleation center to initiate the crystal formation. In addition, specific cellular

435 metabolism could also be involved acting as iron oxidizer or reducer. The biofilms developing in the Sinnamary Estuary, would then present a suitable environment for such mineralization processes. They are indeed mainly constituted of iron $(30-40 \%$ of the DW) and microbial cells. The two iron oxides identified in these biofilms, lepidocrocite and ferrihydrite, could result from physico-chemical reactions or be

440 induced by bacterial activity. The ferrihydrite is a widespread iron oxide and also precipitates in the vicinity of iron oxidizing bacteria (Fortin and Langley, 2005). Lepidocrocite one the other hand, is a relatively scarce iron oxide, it has however a widespread occurrence in suboxic environment such as reductomorphic soils and it is a typical oxidation product of GR (Schwertmann and Taylor, 1989). It was also shown

445 to be the main product of Fe"-oxidizing nitrate reducing bacteria (Larese-Casanova et al., 2010). 
In the biofilms used in the present work, the lepidocrocite exhibited low sized crystals and a weak cristallinity (according to the broad XRD peaks) and the ferrihydrite was not detected by XRD. Such characteristics are typical of natural iron oxides associated with high organic matter, especially for the bacteriogenic ferric iron oxides resulting from a rapid Fe" oxidation (Schwertmann and Taylor, 1989 ; Fortin and Langlet, 2005). Moreover, twisted like structures (Fig. SI-5) suggest the presence of Gallionella sp., a ferrous oxidizing bacteria genous (Ghiorse and Ehrlich, 1992). The low acidic $\mathrm{pH}(\sim 6.5)$ and the significant level of $\mathrm{Fe}^{2+}$ occurring in the Sinnamary estuarine water are also favorable conditions for near-neutral iron oxidizing bacteria (Søgaard et al., 2000 ; Blöthe an Roden, 2009). The bacteria are embedded into an EPS matrix and are in close contact with iron solids supporting the hypothesis of a direct interaction between bacteria and iron oxides. These iron oxides could be the by-product of iron oxidizing bacteria, and could also serve as final electron acceptor

460 for DIRB (Straub et al., 1998). Indeed, the iron reducing bacteria were estimated to represent up to $10^{8}$ cells $\mathrm{g}^{-1}$ in those biofilms (Huguet et al., 2010). As it is usually observed for mature biofilms or bacterial aggregates, the aerobic metabolism of bacteria could significantly affect the redox potential and create strong anaerobic conditions few dozen or hundred $\mu \mathrm{m}$ within a biofilm (Stewart and Franklin, 2008)

465 which would allow the anaerobic respiration of Fe $\mathrm{e}^{\text {III }}$ and subsequently the formation and the stability of secondary Fe"-bearing minerals. The possibility that bacterial Fe" oxidation and $\mathrm{Fe}^{\mathrm{III}}$ reduction could be tightly coupled in such environments have been suggested and documented (Emerson and Mayer, 1997; Sobolev and Roden, 2002; Blöthe and Roden, 2009). 


\subsection{Iron reduction and GR biomineralization}

In order to evaluate the capability of biofilm's iron oxides to be transformed into secondary iron minerals, lyophilized biofilm were used as electron acceptor for $S$. putrefaciens, a bacteria well-known to precipitate GR from lepidocrocite or ferrihydrite bioreduction. The iron reduction rates $\left(0.7 \pm 0.1 \mathrm{mmol} \mathrm{l}^{-1} \mathrm{~h}^{-1}\right.$ from data of Fig. 4$)$ of the ferric material present in the Sinnamary biofilm were in the same order of magnitude comparatively to other studies performed in similar conditions in terms of cells/Fe ${ }^{\prime \prime \prime}{ }_{s}$ ratio and formate concentration (iron reduction rate varied from $\sim 0.1$ to $15 \mathrm{mmol} \mathrm{L}^{-1}$ $480 \quad \mathrm{~h}^{-1}$, Ona-Nguema et al., 2002 ; Zegeye et al., 2007a; O’Loughlin et al., 2007; O'Loughlin et al., 2010; Zegeye et al., 2010). This indicates that the ferric oxides of the biofilms from the Sinnamary River were readily available for bacterial reduction. Indeed, as regards to the proportion of Fe ${ }^{\text {III }}$ reduced, the ferric biofilm material appeared to be more reducible than the synthetic iron oxide (Table 1). This was also noted from previous studies with natural ferric material from another origin (Straub et al., 1998; Blöthe and Roden, 2009). The GR1 (assumed to be the $\mathrm{GR}\left(\mathrm{CO}_{3}{ }^{2-}\right)$ ) was the main secondary mineral produced by the bacterial reduction of the biofilm's iron oxide by $S$. putrefaciens. It has been previously shown that S. putrefaciens CIP 80.40 promotes the GR biomineralization under a high ratio cell density/iron oxide (above $\left.10^{10} \mathrm{mmol}^{-1}\right)$ (Zegeye et al., 2007a; Zegeye et al., 2010). At a lower ratio cells/Fe"II and in absence of significant amount of phosphate or silica, magnetite $\left(\mathrm{Fe}_{3} \mathrm{O}_{4}\right)$ was the main secondary mineral expected as regards to literature data (Fredrickson et al., 1998; Ona-Nguema et al., 2002; Kukkadapu et al., 2004; Zegeye et al., 2007a; Zegeye et al., 2010; Sergent et al., 2010). In the present work, whatever the ratio used, below $\left(0.5 \times 10^{10} \mathrm{mmol}^{-1}\right)$ or above $\left(2 \times 10^{10} \mathrm{mmol}^{-1}\right)$, the GR was the dominant 
secondary iron mineral with minor magnetite formation as indicated by Mössbauer analysis. This indicates that the lyophilized biofilm promotes the GR1 instead of magnetite. The lyophilized biofilm contains a large proportion of organic matter like cellular wastes and probably exo-cellular polymers. Thus, in previous works, it was shown that autoclaved cells, EPS or organic polymers promote the GR precipitation (Zegeye et al., 2007a; Jorand et al., 2008; O'Loughlin et al., 2010). Flocculation and bacterial strains have been also suggested to influence the GR precipitation (Salas et al., 2010; Zegeye et al., 2010). Similar results concerning the secondary mineral were obtained from ferruginous biofilm ("layered natural ferric precipitates") collected

505 from a groundwater seep (Blöthe and Roden, 2009). Therefore, ferruginous biofilms like those found into the Sinnamary Estuary are expected to be favorable for the precipitation of GR since they exhibit EPS and large cell density in a close volume.

\subsection{Green rust ageing and stabilization}

510

The stability of carbonated GR1 is known to be very weak in the absence of stabilizing agents like phosphate, microbial cell suspension, or silicate and is readily transformed, within few hours, into magnetite (Benali et al., 2001; Bocher, et al., 2004; Kukkadapu et al., 2005). The XRD analysis of aged incubation samples at

$51530^{\circ} \mathrm{C}$ in darkness during $800 \mathrm{~d}(\sim 2$ years) showed that the GR1 is still present after a long period of time in the medium, indicating the relative stability of the mineral in those conditions. Only a minor fraction of GR was partially transformed into magnetite and/or calcium magnesium ferrous carbonate. This suggest that the biofilms or the medium (e.g. : phosphate in that case) have provided some materials 520 inducing the stabilization of the GR1. 
It is wellknown that the GR is readily produced from $\gamma$-FeOOH bioreduction in batch experiment with a large cell density of pure strain Shewanella sp. (resting cells). This has been also shown by this work with environmental iron oxides. But when the cell density was lower, i.e. in order to initiate a cell growth or to start with a cell density

525 closer to that found in natural environments (i.e. $<10^{8}$ cells $\mathrm{mL}^{-1}$ ), the extent of the $\mathrm{Fe}^{\text {III }}$ reduction was generally very low and the number of cultivable cells declined with the time (e.g. : Roden and Urrutia, 2002). For such studies, the final product was mainly the magnetite (e.g. : Lovley et al., 1987; Glasauer et al., 2003). However, it was reported by Blöthe and Roden (2009) and from the present study, that the

530 formation of GR1 occurred from environmental sample where the Fe oxide appears to be associated with organic phases. The key role of the organic phases would proceed by stabilizing the GR1 or by initiating its formation instead of another $\mathrm{Fe}$ " bearing mineral.

The organic material associated with the biofilm as well as constituents such as

535 humic-like substances, quartz particles could contribute to GR occurrence as it was suggested by laboratory experiments (O'Loughlin et al., 2010; Sergent et al., 2010). These hypothesis need however to be supported by more data on the nature of the dominate members of the microbial community responsible for the Fe"lI reduction and for the GR formation.

\subsection{GR occurrency in Sinnamary Estuary and biofilms}

The formation of Fe"-bearing minerals, especially the GR mineral can be expected in the biofilm of the Sinnamary river since several conditions are gathered to allow its 545 synthesis: presence of DIRB activity into the biofilm, a readily reducible ferric oxides. 
Moreover, the $\mathrm{pH}$ interval of the Estuary water is close to the $\mathrm{pH}\left(\mathrm{H}_{2} \mathrm{O}\right)$ of the hydromorphic soils where the GR mineral (fougerite) has been identified (Bourrié et al., 1999). However, the mineral has not been yet detected directly in the raw biofilm. One can hypothesize that the GR could be present at very low concentration, below

550 the detection level, or it was oxidized during sampling and/or transportation. The causes could be a lack of electron donor or/and a too high $\mathrm{O}_{2}$ level. Nevertheless, the ferric materials and bacteria constituting these biofilms can potentially support the biomineralization of such interesting mineral serving as electron donor for oxidized chemicals. By extension, one can assume that biofilm could represent an efficient

555 substrate for GR formation. One could speculate that in mercury contaminated area such as the Sinnamary Estuary, the GR has to be taken into account as a potential abiotic mercury attenuation mean of the water phase.

\section{Conclusions}

560 The anaerobic incubation of ferruginous biofilm components with a pool of electron donor can lead to the formation of the Fe"-Fe"l' hydroxysalt green rust from the activity of iron reducing bacteria. In addition, this green rust exhibited a great stability (over than three years in the batch incubation) in the aqueous suspension probably due to the polymeric materials which contribute likely to its stability. The biofilms, such those

565 found in the anthropised Sinnamary Estuary in French Guyana, should therefore be considered as a favorable location for GR biomineralization when redox conditions and electron donors availability are gathered. The presence of this mineral is expected to be in anaerobic pockets within the biofilms, and dedicated analysis on fresh biofilms, preserved from air oxidation, could be conducted to support this 
570 hypothesis. Moreover, this ferrous mineral could also serve as Fe"l source for iron oxidizing bacteria and thus be involved in a cycling of iron at a microscopic scale. Finally, if the presence of green rust in such biofilm is confirmed, it would contribute to the mercury attenuation, which is a pollutant of a major concern in the Sinnamary Estuary, by reducing the $\mathrm{Hg}^{\prime \prime}$ into the volatile $\mathrm{Hg}^{\circ}$. 


\section{Acknowledgements}

The authors would like to thank Guirec Ollivier and Isabelle Bihannic for DRX analysis (LEM UMR 7569, CNRS-INPL, Nancy, France), Cédric Carteret for Raman spectroscopy, Martine Mullet for XPS analysis and Jérome Cortot for ICP-AES analysis (LCPME UMR 7564 CNRS-UHP, Nancy 1). We also thank the HYDRECO laboratory team (Kourou, French-Guiana) for their warm-hearted reception and technical support on the site and Florian Landry, a graduate student, for its technical help. We thank also Christian Ruby for valuable discussion. This work was supported by EDF Industry Hydro Engineering Centre (Le Bourget-du-Lac, France) and by the

585 INSU, French national institute of the universe sciences (INSU, ACI-ECCO convention 0429 FNS). Finally we thank the two anonymous reviewers for constructive comments increasing the quality of the article. 


\section{References}

590 Ahmed IMAM, Benning LG, Kakonvi G, Sumoondur AD, Terrill NJ, Shaw S.

Formation of green rust sulfate: a combined in situ time-resolved X-ray scattering and electrochemical study. Langmuir 2010; 26:6593-603.

Benali O, Abdelmoula M, Refait P, Génin JM. Effect of orthophosphate on the oxidation products of $\mathrm{Fe}(\mathrm{II})-\mathrm{Fe}(\mathrm{III})$ hydroxycarbonate : the transformation of green rust to ferrihydrite. Geochim Cosmochim Acta 2001; 65:1715-26.

Blöthe M, Roden EE. Microbial iron redox cycling in a circumneutral-pH groundwater seep. Appl Environ Microbiol 2009; 75:468-73.

Bocher F, Gehin A, Ruby C, Ghanbaja J, Abdelmoula M, Génin JM. Coprecipitation of $\mathrm{Fe}(\mathrm{II}-\mathrm{III})$ hydroxycarbonate green rust stabilised by phosphate adsorption. Solid

600 State Sci 2004; 6:117-24.

Bourrié G, Trolard F, Génin JMR, Jaffrezic A, Maître V, Abdelmoula M. Iron control by equilibria between hydroxygreen rusts and solutions in hydromorphic soils. Geochim Cosmochim Acta 1999; 63:3417-27.

Brown DA, Kamineni DC, Sawicki JA, Beveridge TJ. Minerals associated with 605 biofilms occurring on exposed rock in a granitic underground research laboratory. Appl Environ Microbiol 1994; 60:3182-91.

Brown DA, Beveridge TJ, Keevil CW, Sherriff BL. Evaluation of microscopic techniques to observe iron precipitation in a natural microbial biofilm. FEMS Microbiol Ecol 1998; 26:297-310.

610 Christiansen BC, Balic-Zunic T, Dideriksen K, Stipp SLS. Identification of green rust in groundwater. Environ Sci Technol 2009; 43:3436-41.

De Beer D, Stoodley P. Microbial biofilms. Prokaryotes 2006; 1:904-37.

De Mérona B, Vigouroux R, Tejerina-Garro FL. Alteration of fish diversity downstream from Petit-Saut Dam in French Guiana. Implication of ecological 615 strategies of fish species. Hydrobiologia 2005; 551:33-47.

Dominique Y. Contamination par les différentes formes chimiques du mercure de la composante biologique du barrage hydroélectrique de Petit-Saut et des zones amont/aval du fleuve Sinnamary, en Guyane francaise (études in situ et approches 
expérimentales). 2006. PhD Thesis, University Bordeaux 1, Bordeaux, France, 366 pages.

Dominique Y, Maury-Brachet R, Muresan B, Vigouroux R, Richard S, Cossa D et al. Biofilm and mercury availability as key factors for mercury accumulation in fish (Curimata cyprinoides) from a disturbed Amazonian freshwater system. Environ Toxicol Chem 2007; 26:45-52.

625 Droppo IG, Flannigan DT, Leppard GG, Jaskot C, Liss SN. Floc stabilization for multiple microscopic techniques. Appl Environ Microbiol 1996; 62:3508-15.

Emerson D, Moyer C. Isolation and characterization of novel lithotrophic ironoxidizing bacteria that grow at circumneutral pH. Appl Environ Microbiol 1997; 63:4784-92.

630 Erbs M, Hansen HCB, Olsen CE. Reductive dechlorination of carbon tetrachloride using iron(II) iron(III) hydroxide sulfate (green rust). Environ Sci Technol 1999; 33:307-11.

Fadrus $\mathrm{H}$, Maly J. Suppression of iron(III) interference in the determination of iron(II) in water by the 1,10-phenanthroline method. Analyst 1975; 100:549-54.

635 Ferris FG, Beveridge TJ, Fyfe WS. Iron-silica crystallite nucleation by bacteria in a geothermal sediments. Nature 1986; 320:609-11.

Fortin D, Langley S. Formation and occurrence of biogenic iron-rich minerals. EarthSci Rev 2005; 72:1-19.

Fredrickson JK, Zachara JM, Kennedy DW, Dong H, Onstott TC, Hinman NW et al. 640 Biogenic iron mineralization accompanying the dissimilatory reduction of hydrous ferric oxide by a groundwater bacterium. Geochim Cosmochim Acta 1998; 62:1920.

Génin JMR, Aissa R, Gehin A, Abdelmoula M, Benali O, Ernsten V et al. Fougerite and $\mathrm{Fe}(\mathrm{II}-\mathrm{III})$ hydroxycarbonate green rust: ordering deprotonation and/or cation 645 substitution; structure of hydrotalcite-like compounds and mythic hydroxide $\mathrm{Fe}(\mathrm{OH})$ (2+x). Solid State Sci 2005; 7:545-72.

Ghiorse WC, Ehrlich HL. Microbial biomineralization of iron and manganese. In: Skinner HCW, Fitzpatrick RW, editors. Biomineralization. Processes of iron and manganese. Cremlingen, Germany: Catena Verlag; 1992. p. 75-99. 
650 Glasauer S, Langley S, Beveridge TJ. Intracellular iron minerals in a dissimilatory iron-reducing bacterium. Science 2002; 295:117-19.

Glasauer S, Weidler PG, Langley S, Beveridge TJ. Controls on Fe reduction and mineral formation by a subsurface bacterium. Geochim Cosmochim Acta 2003; 67:1277-88.

655 Herbillon A. Ferrosic hydroxides, green rusts and fougerite in the biogeochemical cycle of iron. CR Geosci 2006; 33:393-401.

Huguet L, Castelle S, Schäfer J, Blanc G, Maury-Brachet R, Reynouard C et al. Mercury methylation rates of biofilm and plankton microorganisms from a hydroelectric reservoir in French Guiana. Sci Total Environ 2010; 408:1338-48.

660 Jorand F, Appenzeller B, Abdelmoula M, Refait P, Block JC, Génin JMR. Assessment of vivianite formation in Shewanella putrefaciens culture. Environ Technol 2000; 21:1001-05.

Jorand F, Landry F, Zegeye A, Lartiges B, Mustin C. Monitoring green rust biomineralization with polymer addition. Geophysical Research Abstracts, Vol. 10,

665 EGU General Assembly; 2008.

Kukkadapu RK, Zachara JM, Fredrickson JK, Kennedy DW. Biotransformation of two-line silica-ferrihydrite by a dissimilatory Fe(III)-reducing bacterium: formation of carbonate green rust in the presence of phosphate. Geochim Cosmochim Acta 2004; 68:2799-814.

670 Kukkadapu RK, Zachara JM, Fredrickson JK, Kennedy DW, Dohnalkova AC, Mccready DE. Ferrous hydroxyl carbonate is a stable transformation product of biogenic magnetite. Am Mineral 2005; 90:510-15.

Larese-Casanova P, Haderlein SB, Kappler A. Biomineralization of lepidocrocite and goethite by nitrate-reducing $\mathrm{Fe}(\mathrm{II})$-oxidizing bacteria: effect of $\mathrm{pH}$, bicarbonate,

675 phosphate and humic acids. Geochim Cosmochim Acta 2010; 74:2799-814.

Lovley DR, Stolz JF, Nord Jr GL, Phillips EJP. Anaerobic production of magnetite by a dissimilatory iron-reducing microorganism. Nature 1987; 330:252-54.

Loyaux-Lawniczak S, Refait P, Ehrhardt JJ, Lecomte P, Génin JMR. Trapping of Cr by formation of ferrihydrite during the reduction of chromate ions by Iron (II)-Iron(III) 680 hydroxysalt green rusts. Environ Sci Technol 2000; 34:438-43. 
Murad E, Schwertmann U. The influence of crystallinity on the Mössbauer spectrum of lepidocrocite. Mineral Mag 1984; 48:507-11.

Muresan B, Cossa D, Coquery M, Richard S. Mercury sources and transformations in a man-perturbed tidal estuary; the Sinnamary Estuary, French Guiana. Geochim Cosmochim Acta 2008; 72, 5416-30.

Myneni SCB, Tokunaga TK, Brown Jr GE. Abiotic Se redox chemistry in the presence of Fe(II, III)-oxides. Science 1997; 278:1106-09.

O'Loughlin EJ, Kelly SD, Kemner KM, Csencsits R, Cook RE. Reduction of Ag', Au'", $\mathrm{Cu}^{\prime \prime}$, and Hg" by Fe"/Fe"l hydroxysulfate green rust. Chemosphere 2003; 53:437-46.

690 O'Loughlin EJ, Larese-Casanova P, Scherer M. Green rust formation from the bioreduction of $\gamma-\mathrm{FeOOH}$ (lepidocrocite): comparison of several Shewanella species. Geomicrobiol J 2007; 24:211-30.

O’Loughlin EJ, Gorski CA, Scherer MM, Boyanov MJ, Kemner KM. Effects of oxyanions, natural organic matter, and bacterial cell numbers on the bioreduction of lepidocrocite $(\mathrm{\gamma}-\mathrm{FeOOH})$ and the formation of secondary mineralization products. Environ Sci Technol 2010; 44:4570-76.

Ona-Nguema G, Abdelmoula M, Jorand F, Benali O, Géhin A, Block JC et al. Iron (II,III) hydroxycarbonate green rust formation and stabilization from lepidocrocite bioreduction. Environ Sci Technol 2002; 36:16-20.

700 Ona-Nguema G, Benali O, Jorand F, Abdelmoula M, Block JC, Génin JMR. Key role of the kinetics of $\gamma$-FeOOH bioreduction on the formation of $\mathrm{Fe}(\mathrm{II})-\mathrm{Fe}(\mathrm{III})$ minerals. Proc. of the International Conference on the Applications of the Mössbauer Effect. Hyperfine Interact (C) 2003; 5:415-18.

Refait P, Simon L, Génin JMR. Reduction of $\mathrm{SeO}_{4}{ }^{2-}$ anions and anoxic formation of iron(II)-iron(III) hydroxy selenate green rust. Environ Sci Technol 2000; 34:819-25.

Refait P, Abdelmoula M, Génin JMR, Sabot R. Green rusts in electrochemical and microbially influenced corrosion of steel. CR Geosci 2006; 338:476-87.

Richard S, Arnoux A, Cerdan P. Evolution in physico-chemical water quality in the reservoir and downstream following the filling of Petit Saut dam (French Guiana).

710 Hydroécologie Appliquée 1997; 9(1-2):57-83.

Roden EE, Urrutia MM. Influence of biogenic Fe(II) on bacterial crystalline Fe(III) reduction. Geomicrobiol J 2002; 19:209-51. 
Salas EC, Berelson WM, Hammond DE, Kampf AR, Nealson KH. The impact of bacterial strain on the products of dissimilatory iron reduction. Geochim Cosmochim Acta 2010; 74:574-83.

Schwertmann U, Taylor RM. Iron oxides. In: Dixon JB, Weed SB, editors. Minerals in soil environments. Madison, WI: Soil Science Society of America; 1989. p. 379-438.

Sergent AS, Jorand F, Hanna K. Biomineralization of Fe" $-\mathrm{Fe}^{\text {III }}$ species in porous heterogeneous medium of sand/iron oxyhydroxide/bacteria. Proc. of Goldschmidt conference, « Earth, energy and the environment », Knoxville, Tennessee, June 13th - 18th; 2010.

Sobolev D, Roden EE. Characterization of a neutrophilic, chemolithoautotrophic $\mathrm{Fe}(\mathrm{II})$-oxidizing ß-proteobacterium from freshwater wetland sediments. Geomicrobiol J 2004; 21:1-10.

725 Søgaard EG, Medenwaldt R, Abraham-Peskir JV. Conditions and rates of biotic and abiotic iron precipitation in selected Danish freshwater plants and microscopic analysis of precipitate morphology. Water Res 2000; 34:2675-82.

Stewart PS, Franklin MJ. Physiological heterogeneity in biofilms. Nat Rev Microbiol 2008; 6:199-210.

730 Straub KL, Hanzlik M, Buchholz-Cleven BEE. The use of biologically produced ferrihydrite for the isolation of novel iron-reducing bacteria. Syst Appl Microbiol 1998; 21:442-49.

Tamaura $\mathrm{Y}$, Ito K, Katsura T. Transformation of $\gamma$-FeOOH to $\mathrm{Fe}_{3} \mathrm{O}_{4}$ by adsorption of iron(II) ion on $\gamma$-FeOOH. J Chem Soc, Dalton T 1983; 1983:189-94.

735 Trolard F, Génin JMR, Abdelmoula M, Bourrié G, Humbert B, Herbillon AJ. Identification of a green rust mineral in a reductomorphic soil by Mössbauer and Raman spectroscopies. Geochim Cosmochim Acta 1997; 61:1107-111.

Trolard F, Bourrié G, Abdelmoula M, Refait P, Feder F. Fougerite, a new mineral of the pyroaurite-iowaite group: description and crystal structure. Clay Clay Miner $740 \quad 2007 ; 55: 323-34$.

Tronc E, Belleville P, Jolivet JP, Livage J. Transformation of ferric hydroxide into spinel by Fell adsorption. Langmuir 1992; 8:313-19. 
Zegeye A, Ona-Nguema G, Carteret C, Huguet L, Abdelmoula M, Jorand F. Formation of hydroxysulphate green rust 2 as a single iron(II-III) mineral in 745 microbial culture. Geomicrobiol J 2005; 22:389-99.

Zegeye A, Ruby C, Jorand F. Kinetic and thermodynamic analysis during dissimilatory $\gamma-\mathrm{FeOOH}$ reduction: formation of green rust 1 and magnetite. Geomicrobiol J 2007a; 24:1-14.

Zegeye A, Huguet L, Abdelmoula M, Carteret C, Mullet M, Jorand F. Biogenic hydroxysulfate green rust, a potential electron acceptor for SRB activity. Geochim Cosmochim Acta 2007b; 71 :5450-62.

Zegeye A., Mustin C., Jorand F. Bacterial and iron oxide aggregates mediate secondary iron mineral formation: green-rust vs magnetite. Geobiology 2010; 8:209-22. 
Table 1. Characteristics of the incubation flasks for the biomineralization tests and secondary iron minerals resulting of the DIRB activity at $30^{\circ} \mathrm{C} . \pm S D$ are calculated from duplicate or triplicate incubation flasks or from duplicate analysis on a single sample. Since no detectable $\mathrm{Fe}^{\prime \prime}$ was present in the raw biofilm sample, $\mathrm{Fe}_{\text {tot }}$ is assumed to correspond to $\mathrm{Fe}^{\mathrm{II \prime}}$.

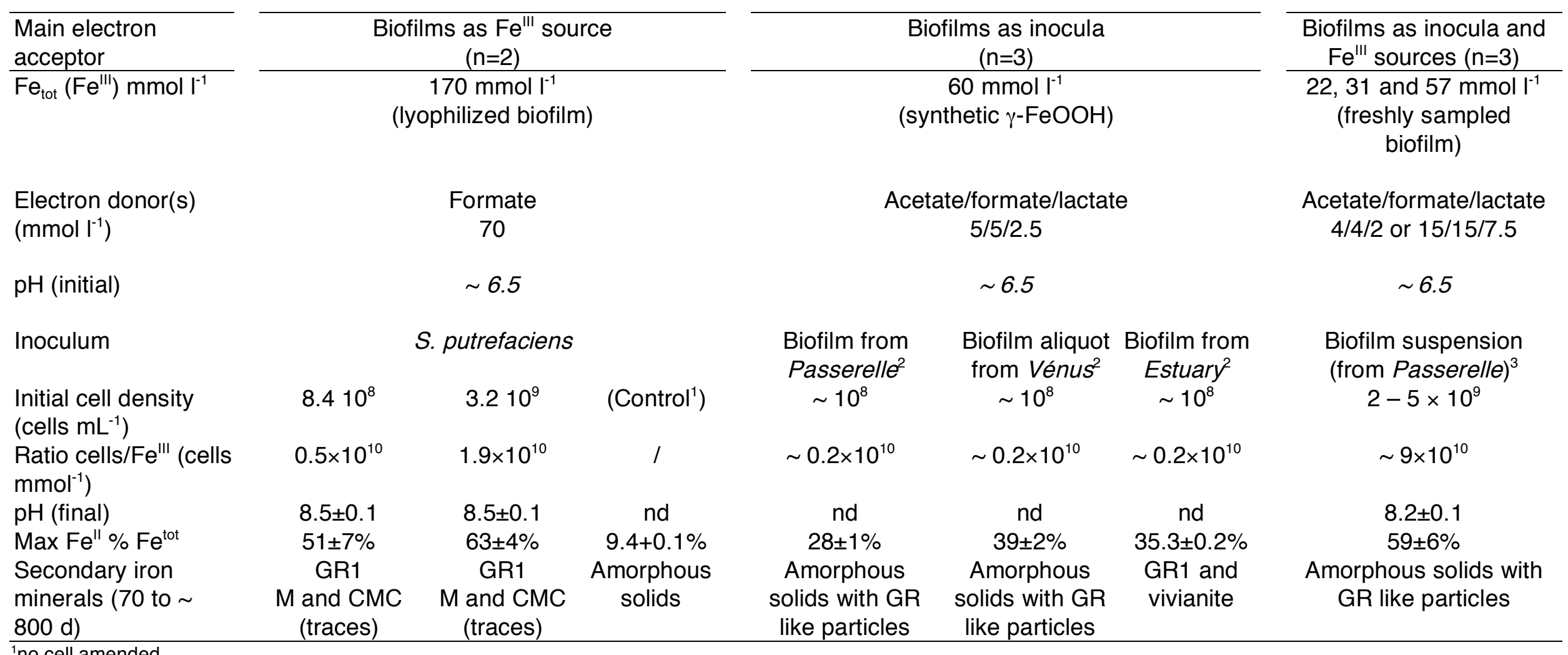

${ }^{1}$ no cell amended.

5 2these inocula consisted by suspensions from biofilms or deposits diluted in the estuarine water, $10 \%$ (V/V) of these suspensions were used as inocula.

${ }^{3} 60-90 \%(\mathrm{~V} / \mathrm{V})$ of a biofilm suspension. $\mathrm{nd}=$ not determined. 
Table 2. Physico-chemical characteristics of the water phase and of the ferruginous biofilms at the river stations Passerelle and Vénus (collected in June 2007). DW = dry weight, AFDW $=$ ash free dry weight, $\mathrm{nd}=$ not determined.

\begin{tabular}{|c|c|c|}
\hline \multirow[b]{2}{*}{ Parameters } & \multicolumn{2}{|c|}{ Station } \\
\hline & Passerelle & Vénus \\
\hline \multicolumn{3}{|l|}{ Estuarine water $^{a}$} \\
\hline $\mathrm{pH}$ & 5.8 & 5.6 \\
\hline $\mathrm{O}_{2} \mathrm{mg} \mathrm{l}^{-1}(\%)$ & $5.1(65)$ & $4.5(58)$ \\
\hline$E_{\mathrm{h}} \mathrm{mV}$ & \multicolumn{2}{|c|}{$243-321$} \\
\hline $\mathrm{PO}_{4}^{3-} \mu \mathrm{g} \mathrm{I}^{-1}$ & 16.5 & 17.8 \\
\hline $\mathrm{NH}_{4}^{+} \mu \mathrm{g} \mathrm{I}^{-1}$ & 159 & 152 \\
\hline $\mathrm{Fe}^{11}{ }_{\mathrm{aq}} \mu \mathrm{g} \mathrm{l}^{-1}$ & $922\left(\sim 16 \mu \mathrm{mol} \mathrm{l}^{-1}\right)$ & $536\left(\sim 10 \mu \mathrm{mol} \mathrm{l}^{-1}\right)$ \\
\hline $\mathrm{Tp}^{\circ} \mathrm{C}$ & \multicolumn{2}{|c|}{$26.8-28.3$} \\
\hline
\end{tabular}

\section{Biofilms}

\begin{tabular}{|c|c|c|}
\hline DW $\left(g^{-2}\right)^{b}$ & $30-40^{b}$ & nd \\
\hline AFDW (\% DW) & $35 \pm 4(n=16)$ & $34 \pm 4(n=3)$ \\
\hline $\operatorname{Fe}\left(\mathrm{g} \mathrm{g}^{-1} \mathrm{DW}\right)^{\mathrm{c}}$ & $0.37 \pm 0.01(n=3)$ & $0.20 \pm 0.01(n=3)$ \\
\hline $\mathrm{Fe}^{\mathrm{d}}$ & $8-13 \%(26-38 \%)$ & nd \\
\hline $\mathrm{O}\left(\mathrm{O}_{2}^{-}, \mathrm{R}-\mathrm{OH}, \mathrm{H}_{2} \mathrm{O}\right)^{\mathrm{d}}$ & $33-35 \%(27-33 \%)$ & nd \\
\hline $\mathrm{N}\left(-\mathrm{NH}_{2}, \mathrm{NH}_{2}^{+}\right)^{d}$ & $2.6-2.7 \%(1.9-2.2 \%)$ & nd \\
\hline $\begin{array}{c}\mathrm{C}(-\mathrm{C}, \mathrm{H} ; \mathrm{C}-\mathrm{O}, \mathrm{H} ; \\
\mathrm{C}=\mathrm{O})^{\mathrm{d}}\end{array}$ & $51-54 \%(32-38 \%)$ & nd \\
\hline $\begin{array}{c}\mathrm{S}\left(\mathrm{R}-\mathrm{S}-, \mathrm{S}^{2-} \ldots\right)^{\mathrm{d}} \\
\text { Bacteria } \\
\left(\text { cells g }{ }^{-1} \mathrm{DW}\right)\end{array}$ & $\begin{array}{c}0.17-0.18 \%(0.28-0.33 \%) \\
6 \pm 3 \times 10^{11}\end{array}$ & $\begin{array}{c}\text { nd } \\
1.3 \pm 0.5 \times 10^{11}\end{array}$ \\
\hline $\begin{array}{l}r \text { at the Passerelle sta } \\
m \text { ICP-AES analysis. }\end{array}$ & 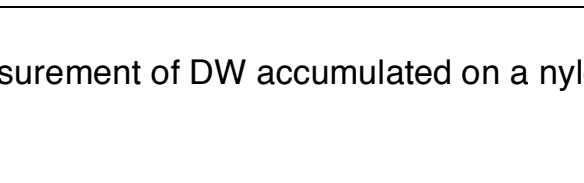 & \\
\hline
\end{tabular}


Figure legends:

Figure 1. Map showing the location of the Petit-Saut dam and the stations Passerelle,

Vénus and Estuary (indicated as a white star) along the Sinnamary Estuary in French Guiana. The semi-circle indicates the location of the dam.

Figure 2. Pictures of the ferruginous biofilms at the Passerelle (a, c, d, e, f) or at the Vénus stations (b). Photography of the biofilms recovering a tube $(5 \mathrm{~cm}$ in diameter)

10 or leaflets as substrata at Passerelle and Vénus stations, respectively. Optical microscopy picture showing bacterial microcolonies $(\mathrm{mc})$ embedded in organic or Febearing gel like matrix, organic matter appears in blue due to the Azur blue coloration (c). Transmission electron microscopy showing close interaction between bacteria and ferruginous material (d), a crumpled paper like Fe-phase (the inset image

15 represents a selected area electron diffraction pattern revealing the solids as lepidocrocite) (e), and a non-diffracting granular Fe-phase (f).

Figure 3. a) X-ray diffractogram (Co, $\lambda=0.17902 \mathrm{~nm}$ ) and b) Raman spectra of the lyophilized ferruginous biofilm (a), chemically synthesized ferrihydrite-2-lines $(b)$ and

20 lepidocrocite $(c)$ as references. Si means $\mathrm{SiO}_{2}$, $\mathrm{L}$ means lepidocrocite and $\mathrm{F}$ means ferrihydrite.

Figure 4. Reduction course of the iron oxide constituting the lyophilized biofilm and inoculated with Shewanella putrefaciens cells. The total $\mathrm{Fe}^{\prime \prime}$ consist in both $\mathrm{Fe}^{2+}$ in the 25 soluble and solid phases. The anaerobic incubation of the lyophilized biofilm (25 $\left.\mathrm{g} \mathrm{I}^{-1}\right)$ 
was done with $70 \mathrm{mmol} \mathrm{I}^{-1}$ of formate as the electron donor and with $S$. putrefacioens cells in duplicate at $8.4 \times 10^{8}$ (open triangle) or $3.2 \times 10^{9}$ (close triangle) cells $\mathrm{ml}^{-1}$. No cell was added in the control (open circle).

Figure 5. X-ray diffractograms (Co, $\lambda=0.17902 \mathrm{~nm}$ ) of the lyophilized biofilm incubated with a resting cell suspension of Shewanella putrefaciens (LC, $8.4 \times 10^{8}$ cells $\mathrm{ml}^{-1}$ and $\mathrm{HC}, 3.2 \times 10^{9}$ cells $\mathrm{ml}^{-1}$ ) or without Shewanella (control). All analysis were made after $70 \mathrm{~d}$ of incubation time, an additional analysis was made at $800 \mathrm{~d}$ with $3.2 \times 10^{9}$ cells $\mathrm{ml}^{-1}$. GR1 means green rust 1 ; $\mathrm{M}$, means magnetite and $\mathrm{CMC}$ 35 means Calcium Magnesium Iron Carbonate.

Figure 6. TEM micrograph (a) and SEM micrograph (b) of GR crystals from incubation of the lyophilized biofilm with $S$. putrefaciens (70 d of incubation time); optical and TEM pictures from incubation of synthetic $\gamma$-FeOOH with aliquot from

40 Estuary surface sediment (180 d of incubation time) indicating a GR like crystals (arrow) within an aggregate of iron oxides (c) and a GR crystal with its electron diffraction pattern (d); TEM and optical pictures from incubation of fresh biofilms supplemented with electron donor showing solid diffracting as an hexagonal symmetry and GR like particles (arrow) (180 d of incubation time) (e, f). 

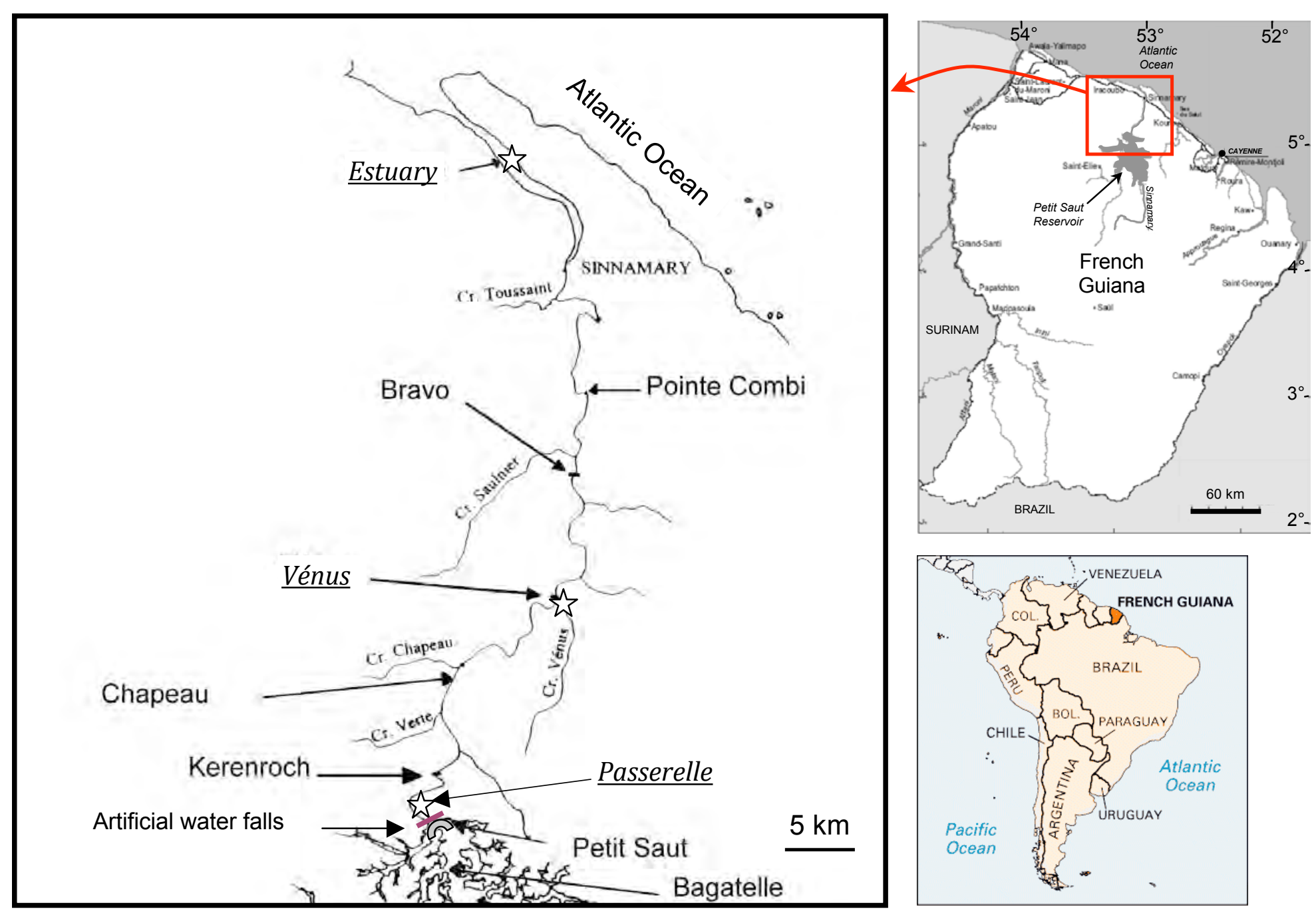


\section{Fiqure 2}
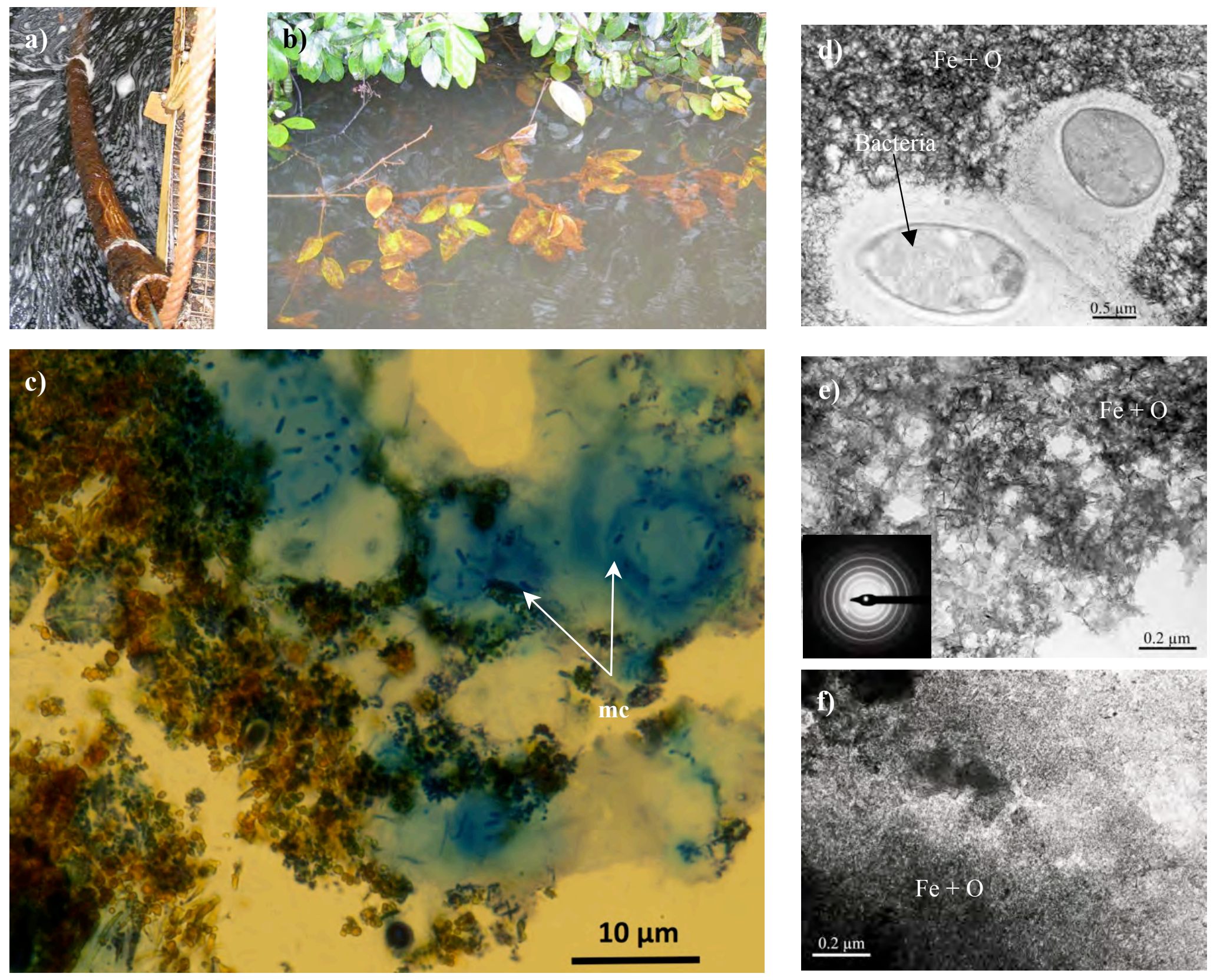


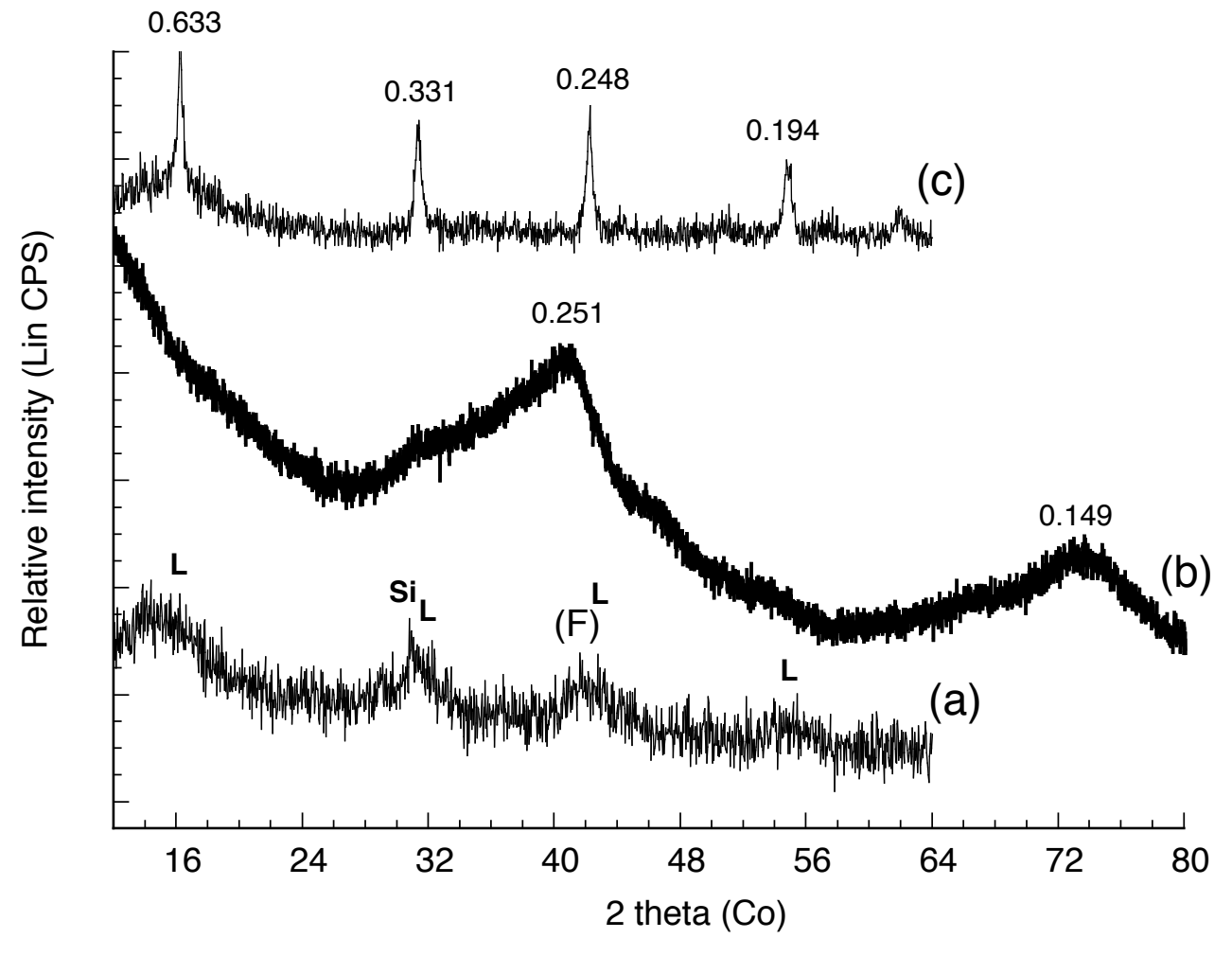

a)

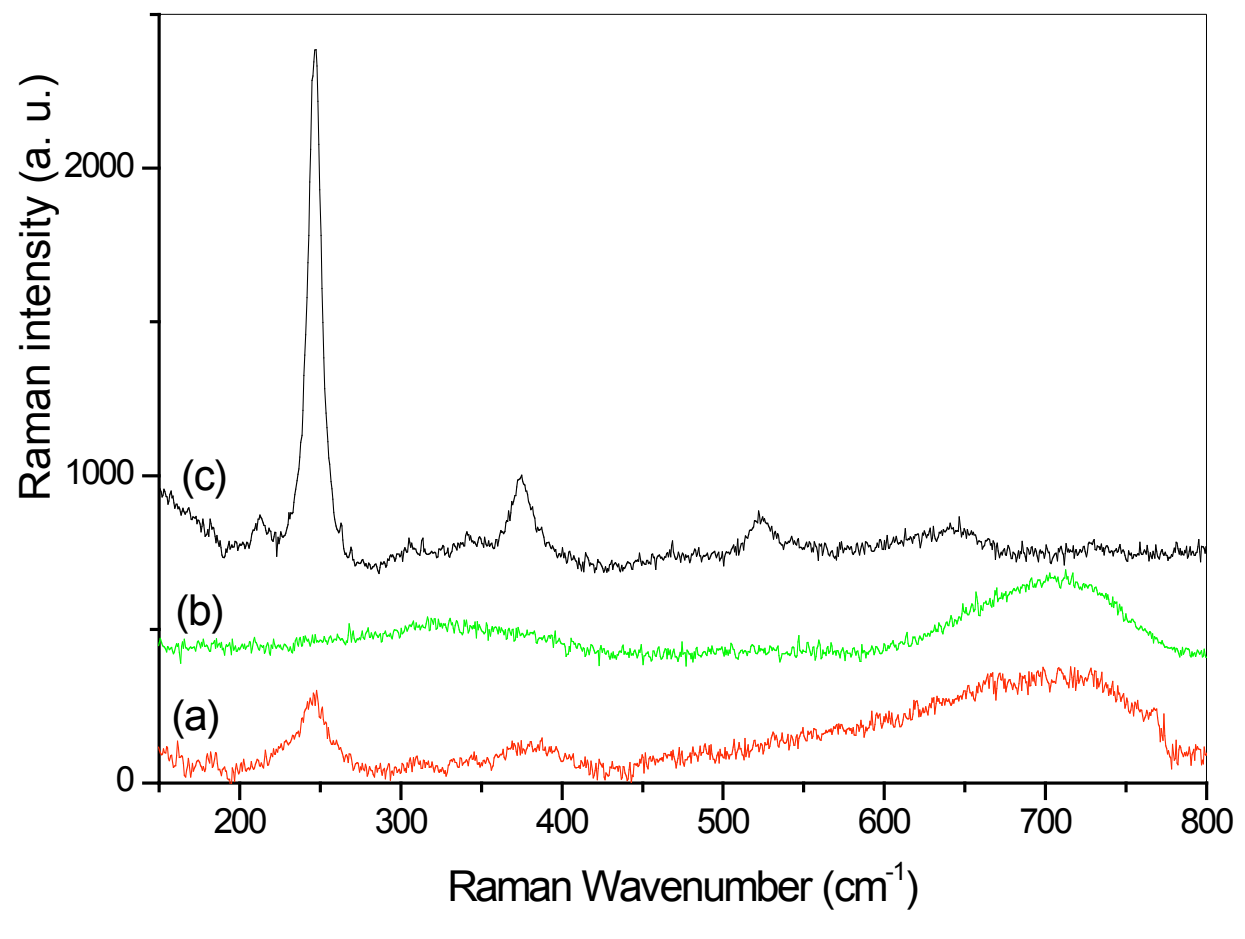

Figure 3. 


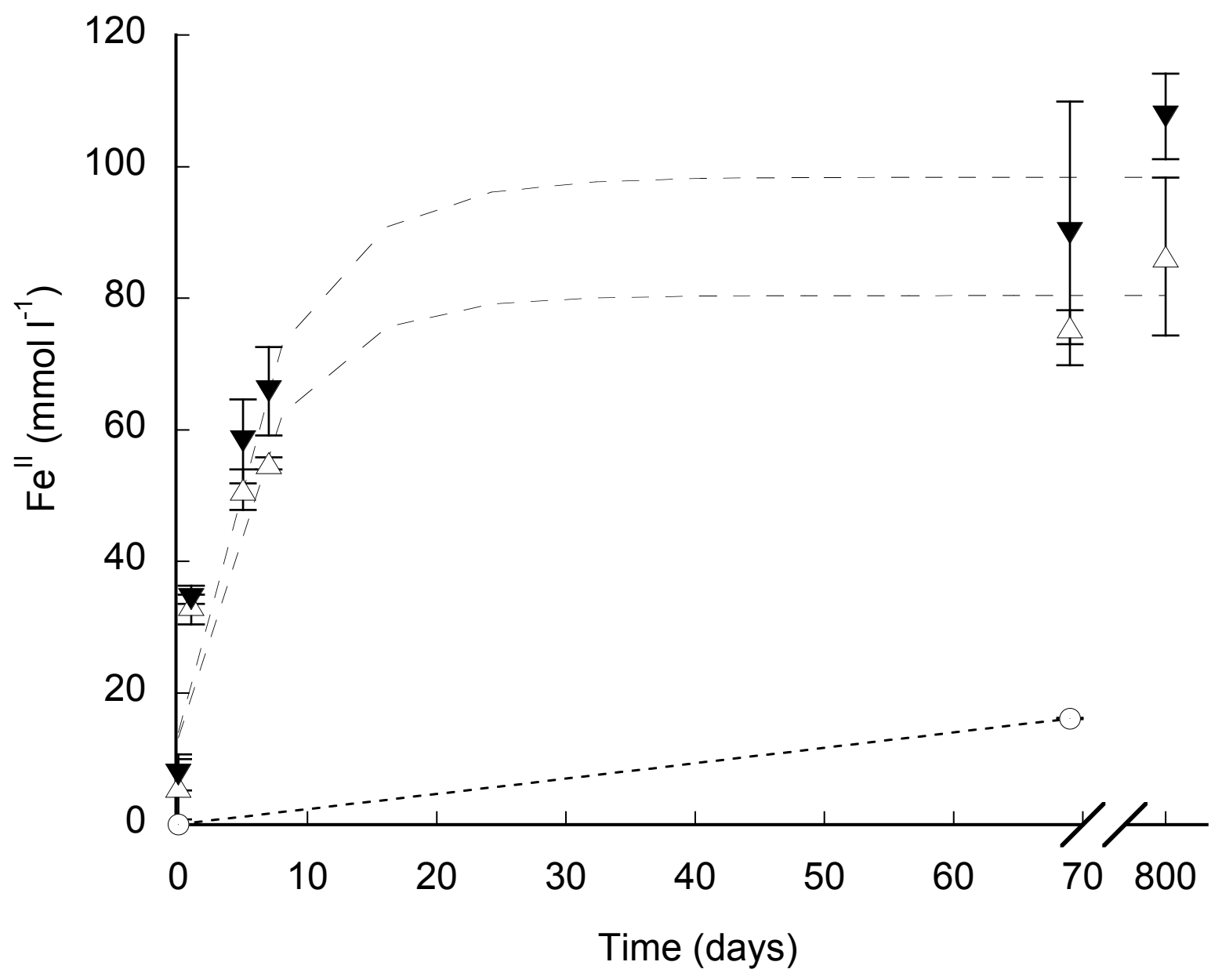

5

Figure 4. 
Fig. 5

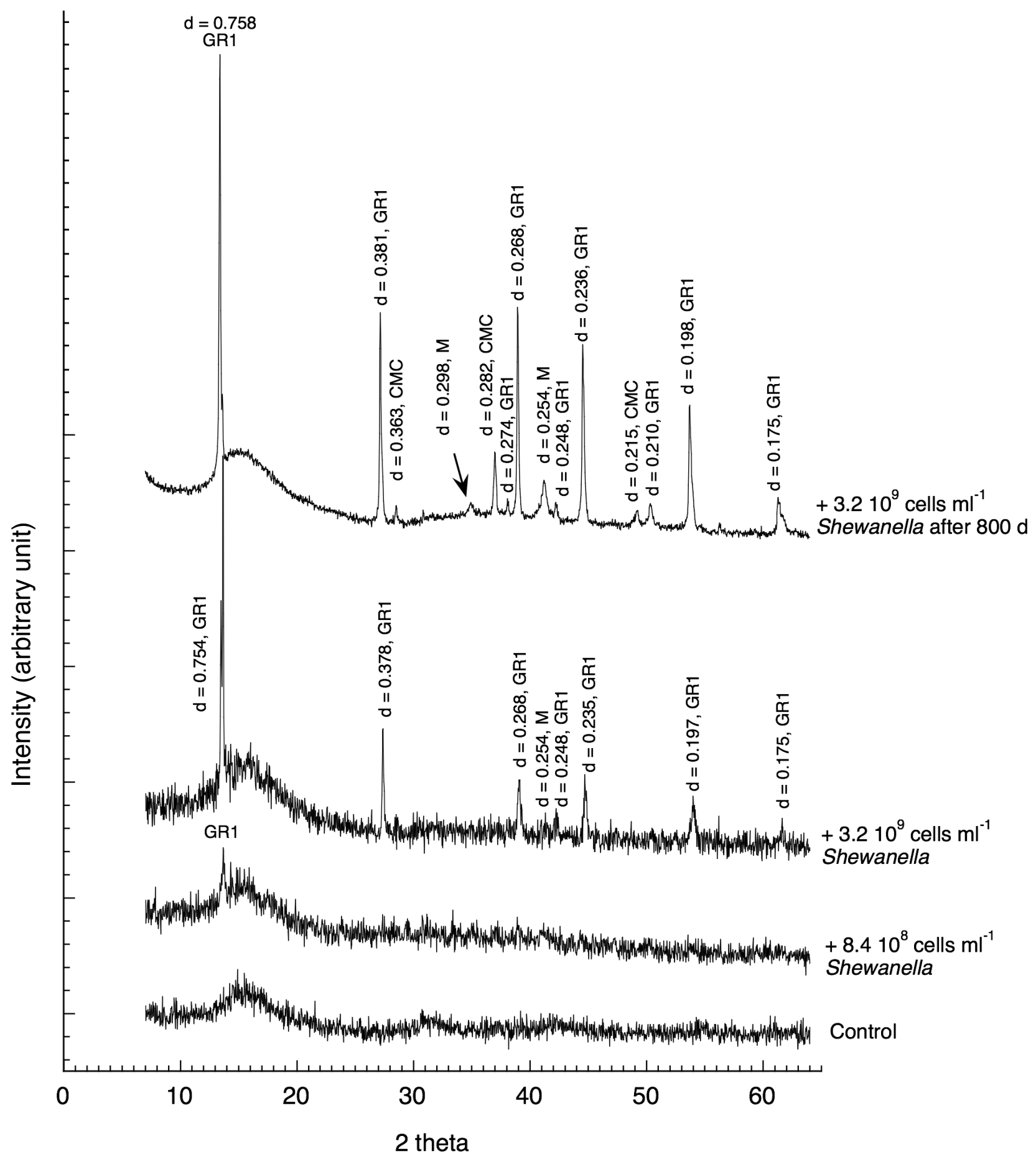



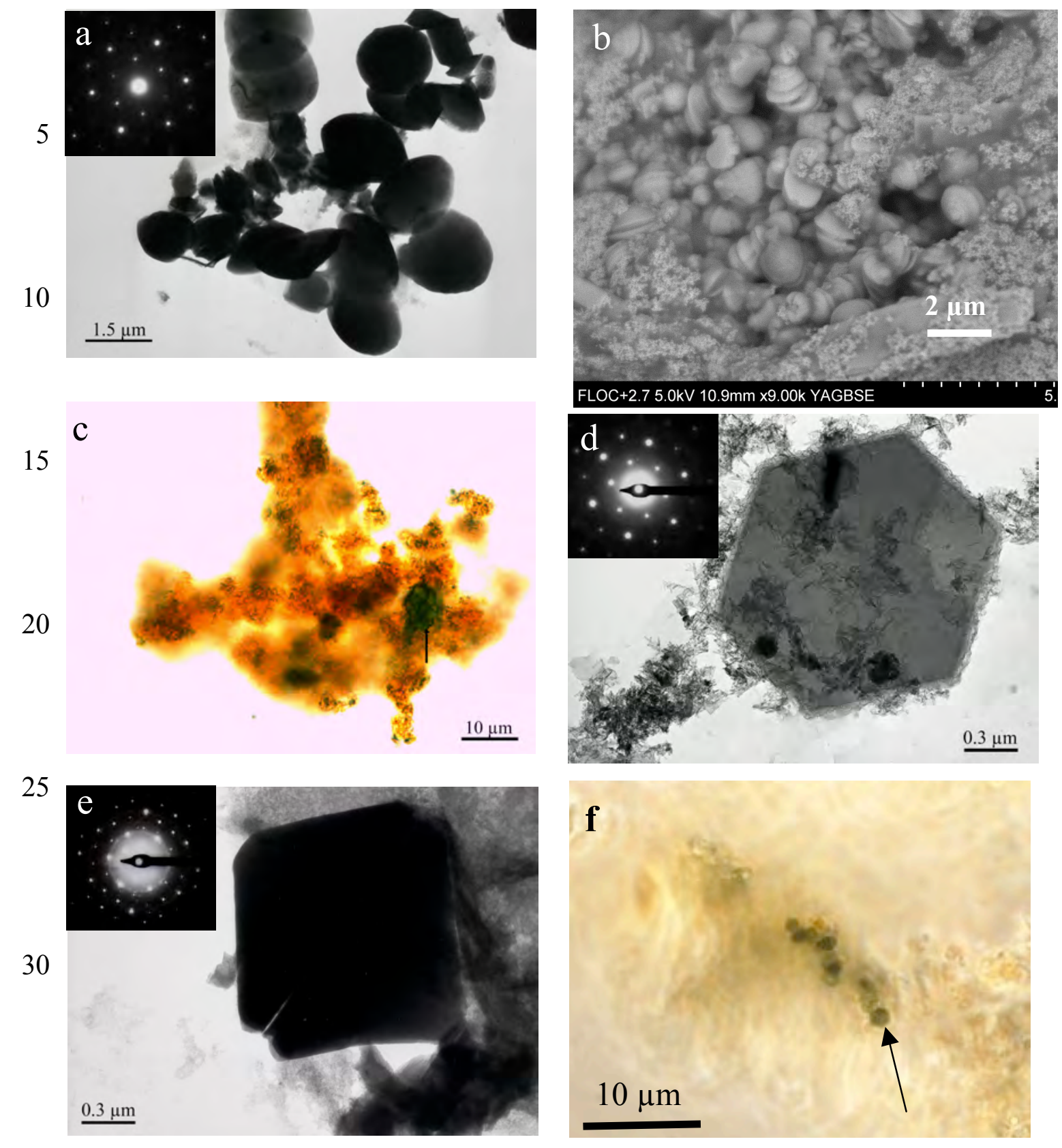

35

40

Figure 6. 


\section{Supporting information}

The formation of green rust induced by tropical river biofilm components

Table SI-1. Quantification report from XPS analysis

\begin{tabular}{ccccccc}
\hline Peak & $\begin{array}{c}\text { Position } \\
\mathrm{BE}(\mathrm{eV})\end{array}$ & $\begin{array}{c}\text { FWHM } \\
(\mathrm{eV})\end{array}$ & $\begin{array}{c}\text { Raw area } \\
(\mathrm{cps})\end{array}$ & RSF & $\begin{array}{c}\text { Atomic conc } \\
\%\end{array}$ & $\begin{array}{c}\text { Mass conc. } \\
\%\end{array}$ \\
\hline $\mathrm{Fe}_{2} \mathrm{p}$ & 710.788 & 3.777 & 14822.1 & 1.971 & 8.33 & 27.13 \\
$\mathrm{O}_{1} \mathrm{~s}$ & 530.888 & 3.332 & 23741.1 & 0.780 & 35.00 & 32.65 \\
$\mathrm{~N}_{1} \mathrm{~s}$ & 399.588 & 2.147 & 1104.9 & 0.477 & 2.73 & 2.23 \\
$\mathrm{C}_{1} \mathrm{~s}$ & 284.588 & 1.522 & 12348.2 & 0.278 & 53.76 & 37.66 \\
$\mathrm{~S}_{2} \mathrm{p}$ & 162.988 & 2.016 & 91.7 & 0.668 & 0.18 & 0.33 \\
\hline
\end{tabular}

Table SI-2. $d_{h k l}$ parameters of lepidocrocite from literature and from this study.

\begin{tabular}{|c|c|c|c|c|}
\hline \multirow[t]{2}{*}{$(h k l)$} & \multicolumn{2}{|c|}{$d_{\mathrm{hkl}}(\mathrm{nm})$ from literature } & \multicolumn{2}{|c|}{$\mathrm{d}_{\mathrm{hkl}}(\mathrm{nm})$ from this study } \\
\hline & $\operatorname{Ref}^{a}$ & $\operatorname{Ref}^{b}$ & $\begin{array}{c}\text { By electronic } \\
\text { diffraction (Fig. 2c) }\end{array}$ & $\begin{array}{l}\text { By XRD } \\
\text { (Fig. 3a) }\end{array}$ \\
\hline$(200)$ & 0.626 & 0.634 & - & $0.620-0.765$ \\
\hline (210) & 0.329 & 0.333 & 0.331 & $0.322-0.332$ \\
\hline (301) & 0.247 & 0.250 & 0.244 & $0.243-0.256$ \\
\hline (111) & 0.238 & 0.236 & 0.237 & $0.233-0.241$ \\
\hline (501) & 0.193 & 0.196 & 0.195 & $0.192-0.197$ \\
\hline
\end{tabular}

${ }^{a}$ Cornell and Schwertmann (1996).

b Zegeye et al. (2007).

Table SI-3. Mössbauer hyperfine parameters of spectra measured at room temperature of the lyophilized ferruginous biofilms.

\begin{tabular}{llll} 
& $\delta\left(\mathrm{mm} \mathrm{s}^{-1}\right)$ & $\Delta\left(\mathrm{mm} \mathrm{s}^{-1}\right)$ & $\mathrm{RA}$ \\
\hline$D_{\mathrm{L}}$ & 0.33 & 0.55 & $74 \%$ \\
$\mathrm{D}_{\mathrm{F}}$ & 0.34 & 0.91 & $26 \%$ \\
\hline
\end{tabular}

$\delta=$ isomer shift taking $\alpha$-iron as reference at ambient; $\Delta$, quadrupole splitting; RA, relative abundance. $D_{L}=$ doublet from lepidocrocite; $D_{F}=$ doublet from ferrihydrite. 
Table SI-4. $d_{h k l}$ parameters of $\mathrm{GR} 1\left(\mathrm{CO}_{3}{ }^{2-}\right)$ from literature and from this study.

\begin{tabular}{|c|c|c|c|c|c|}
\hline \multirow[t]{2}{*}{$(h k l)$} & \multicolumn{3}{|c|}{$\mathrm{d}_{\mathrm{hkl}}(\mathrm{nm})$ from literature } & \multicolumn{2}{|c|}{$d_{h k l}(n m)$ from this study (Fig. 5) } \\
\hline & Ref. $^{a}$ & Ref. $^{b}$ & Ref. $^{\mathrm{C}}$ & Electronic diffraction & XRD \\
\hline$(003)$ & 0.7530 & 0.751 & 0.755 & - & $0.752-0.764$ \\
\hline$(006)$ & 0.3759 & 0.373 & 0.381 & - & $0.378-0.381$ \\
\hline (101) & 0.2720 & 0.273 & 0.274 & - & 0.274 \\
\hline (012) & 0.2668 & 0.265 & $\begin{array}{l}0.269 \\
0.267^{d}\end{array}$ & 0.272 & 0.268 \\
\hline (015) & 0.2344 & 0.233 & - & - & $0.235-0.236$ \\
\hline (018) & 0.1967 & 0.196 & 0.198 & - & $0.197-0.198$ \\
\hline$(0012)$ & 0.1880 & 0.188 & 0.190 & - & $0.188-0.190$ \\
\hline$(10 \underline{10})$ & 0.1740 & 0.173 & 0.175 & - & 0.175 \\
\hline$(120)$ & 0.1550 & & $0.156^{\mathrm{d}}$ & 0.158 & - \\
\hline
\end{tabular}

${ }^{a}$ Hansen et al. (1989).

${ }^{\mathrm{b}}$ Drissi et al. (1995).

25 c Jorand et al. (2007).

d Data from electronic diffraction.

Table SI-5. Mössbauer hyperfine parameters of spectra measured at room temperature after bioreduction of the lyophilised biofilm by Shewanella putrefaciens.

\begin{tabular}{llllr} 
& $\delta\left(\mathrm{mm} \mathrm{s}^{-1}\right)$ & $\Delta\left(\mathrm{mm} \mathrm{s}^{-1}\right)$ & $\mathrm{H}(\mathrm{kOe})$ & $\mathrm{RA}$ \\
\hline $\mathrm{D}_{1}\left(\mathrm{Fe}^{\mathrm{II}}{ }_{\mathrm{GR}}\right)$ & 1.21 & 1.99 & & $35 \%$ \\
$\mathrm{D}_{4}\left(\mathrm{Fe}^{\prime \prime \prime}{ }_{G R}\right)$ & 0.34 & 0.57 & & $25 \%$ \\
$\mathrm{D}_{3}\left(\mathrm{Fe}_{\mathrm{CMC}}\right)$ & 1.12 & 2.66 & & $13 \%$ \\
$\mathrm{D}_{2}\left(\mathrm{Fe}_{\llcorner}{ }_{\mathrm{L}}\right)$ & 0.15 & 0.47 & 483 & $7 \%$ \\
$\mathrm{~S}_{1}$ (magnetite) & 0.28 & 0 & $6 \%$ \\
$\mathrm{~S}_{2}$ (magnetite) & 0.62 & 0 & 452 & $13 \%$ \\
\hline
\end{tabular}

$\delta=$ isomer shift taking $\alpha$-iron as reference at ambient; $\Delta$, quadrupole splitting; RA, relative abundance; $\mathrm{H}$; hyperfine field. $\mathrm{GR}=$ green rust, $\mathrm{CMC}=$ Calcium Magnesium Iron Carbonate.

References

Cornell RM, Schwertmann U (1996) The iron oxides: structure, properties, reactions, occurrences and uses, $\mathrm{VCH}$, Weinheim, Germany.

Hansen HCB (1989) Composition, stabilization, and light absorption of $\mathrm{Fe}(\mathrm{II}) \mathrm{Fe}(\mathrm{III})$ hydroxy carbonate Green Rust. Clay Minerals 24, 663-669.

Drissi H, Refait P, Abdelmoula M, Génin JMR (1995) The preparation and thermodynamic properties of $\mathrm{Fe}(\mathrm{II})-\mathrm{Fe}(\mathrm{III})$ hydroxide-carbonate (Green Rust 1);

Pourbaix diagram of iron in carbonate-containing aqueous media. Corrosion Sciences 37, 2025-2041.

Jorand F, Zegeye A, Landry F, Ruby C (2007) Reduction of ferric green rust by Shewanella putrefaciens. Letters in Applied Microbiology 45, 515 - 521. 


\section{Supporting information}

The formation of green rust induced by tropical river biofilm components

\section{SI Figure Caption:}

Fig. SI-1. EDX analysis of the second phase analyzed from the biofilm (from Fig. 2f).

Fig. SI-2. Mössbauer spectra measured at ambient temperature of the lyophilized biofilm. See Table SI-2 for indication.

Fig. SI-3. Mössbauer spectra measured at ambient temperature of the lyophilised biofilm after bioreduction by Shewanella putrefaciens. See Table SI-4 for indication.

Fig. SI-4. X-ray diffractogram (Co, I = $0.17902 \mathrm{~nm}$ ) of the solids from incubation of synthetic $\gamma$-FeOOH with aliquot from Estuary surface sediment $(\sim 3$ years of incubation time) indicating green rust (GR1) and vivianite (V).

Fig. SI-5. Images from fresh ferruginous biofilms (Passerelle site) showing elements (arrows) suggesting twisted like structure from Gallionella sp., by optical microscopy (a) and by scanning electronic microscopy (b). 


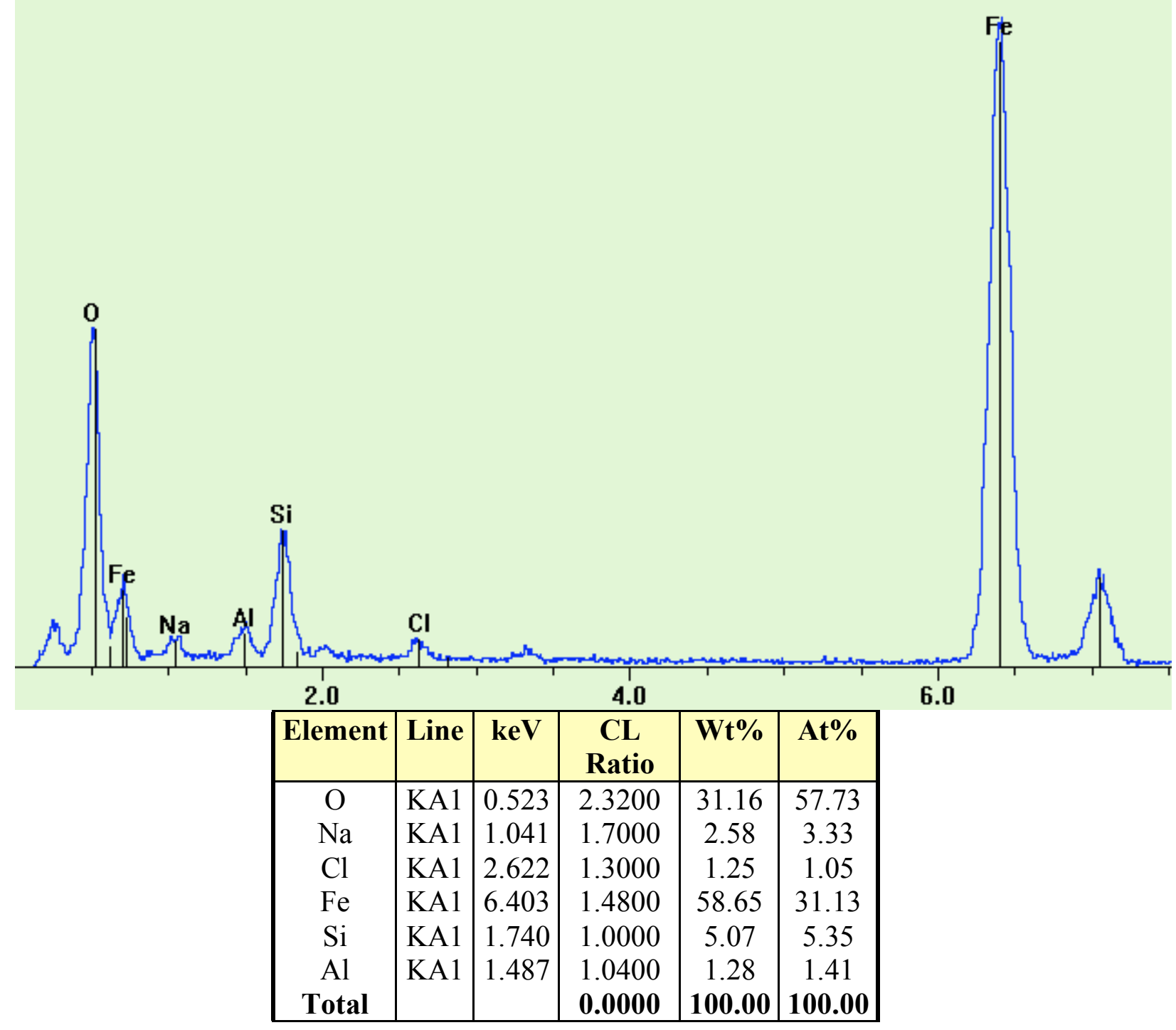

Fig. SI-1 


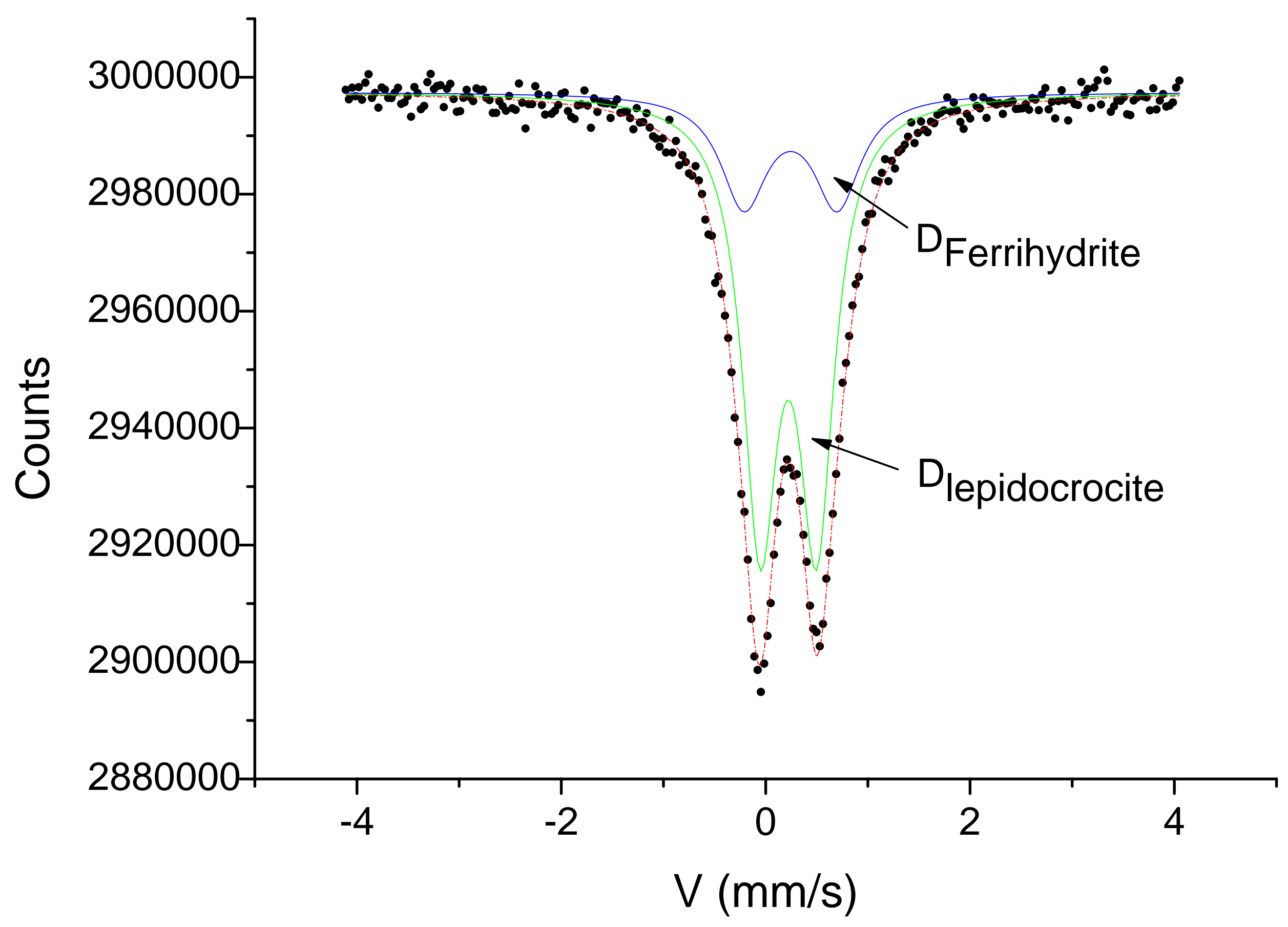




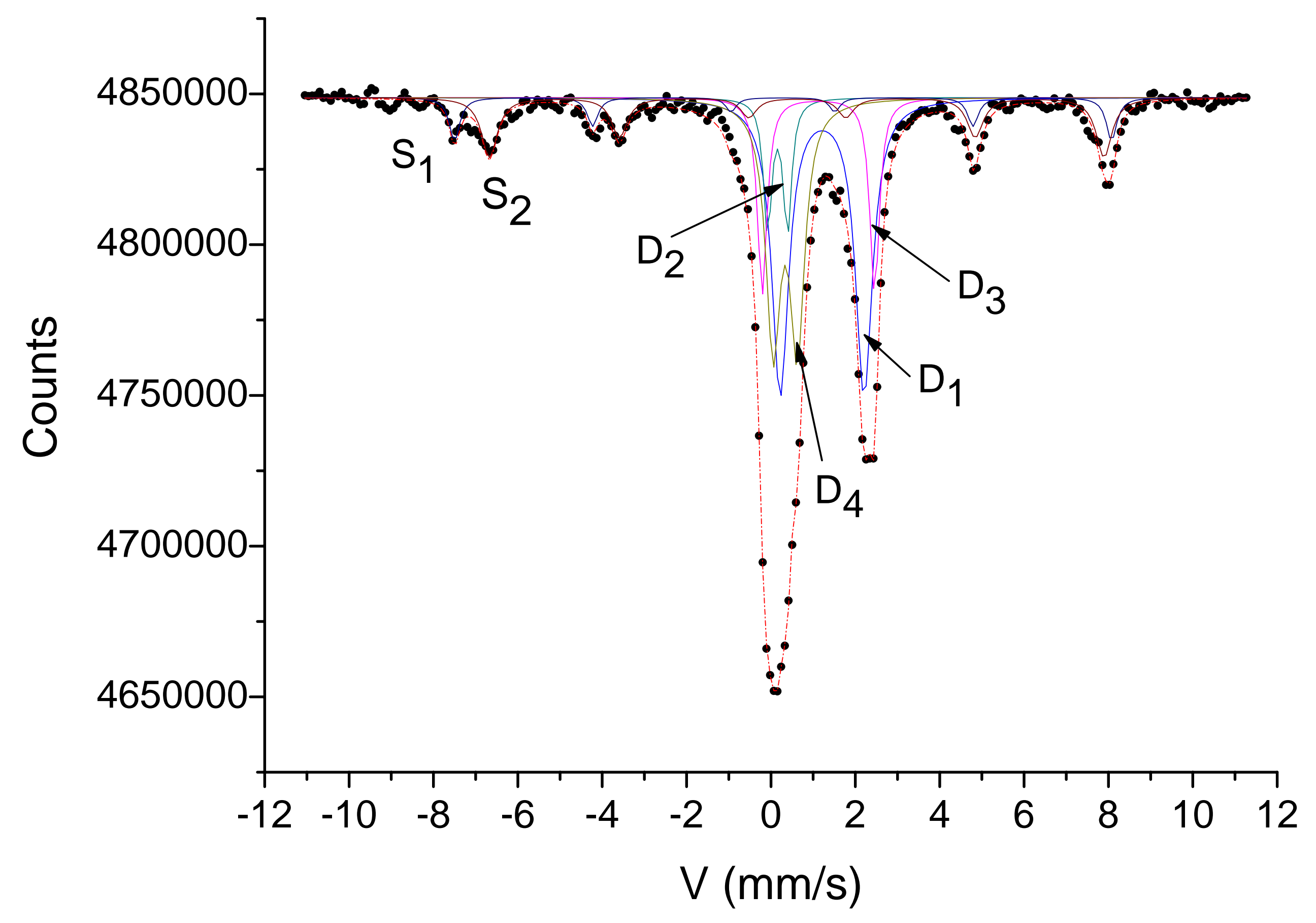




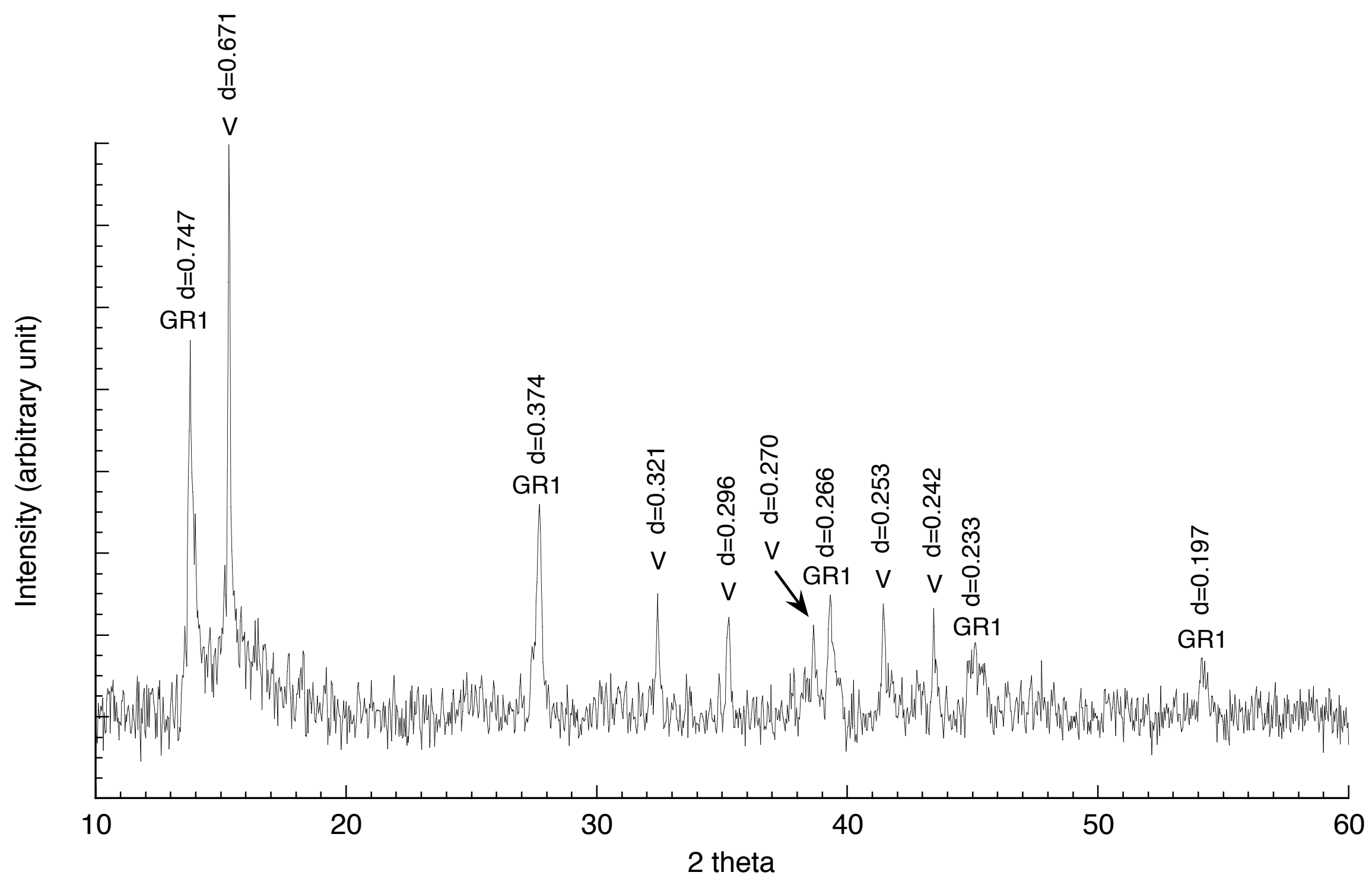

Figure SI-4 


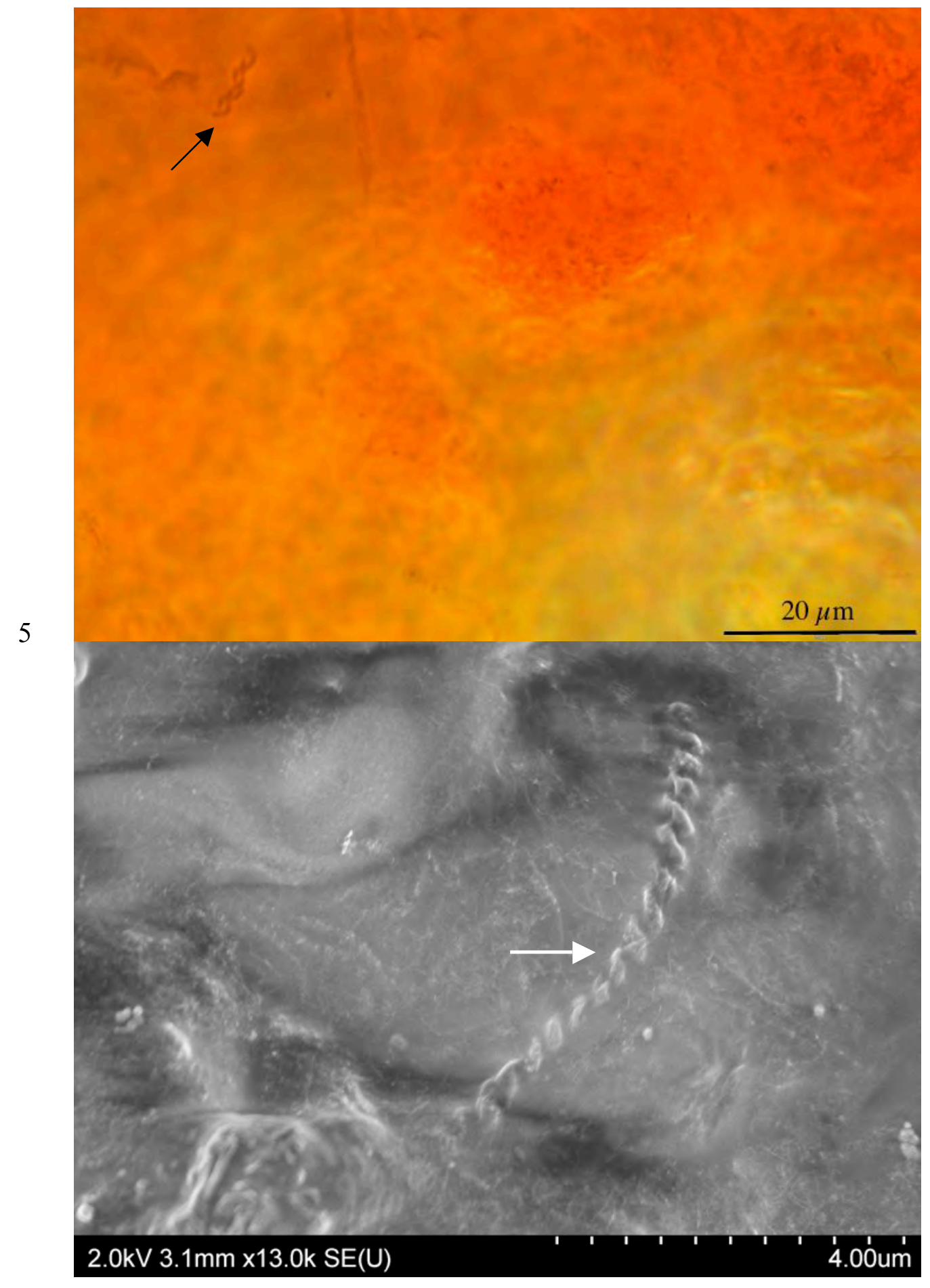

Fig. SI-5 